\title{
MULTI-DIMENSIONAL COMPETENCY ASSESSMENT: AN APPLICATION IN AIRCRAFT MAINTENANCE ORGANIZATION
}

DOI: 10.17261/Pressacademia.2021.1401

RJBM- V.8-ISS.2-2021(5)-101-128

Ferit Saitoglu ${ }^{1}$, Sinan Apak ${ }^{2}$

${ }^{1}$ Bahcesehir University, Business Administration Master's Program, Istanbul, Turkey. ferit.saitoglu@gmail.com, ORCID: 0000-0001-6211-1214

${ }^{2}$ Maltepe University, Engineering and Natural Sciences Faculty, Istanbul, Turkey. sinanapak@maltepe.edu.tr, ORCID: 0000-0002-3263-7167

\begin{tabular}{l}
\hline Date Received: April 4, $2021 \quad$ Date Accepted: June 7, $2021 \quad$ open OACcess \\
\hline To cite this document \\
Saitoglu, F., Apak, S. (2021). Multi-dimensional competency assessment: An application in aircraft maintenance organization. Research Journal of \\
Business and Management (RJBM), 8(2), 101-128. \\
Permanent link to this document: $h$ http://doi.org/10.17261/Pressacademia.2021.1401 \\
Copyright: Published by PressAcademia and limited licensed re-use rights only.
\end{tabular}

\section{ABSTRACT}

Purpose- The effectiveness of maintenance activities is linked to competency of maintenance staff. Because of different operational conditions, various types of competencies and aircraft with complex systems, it is a difficult process to decide in which direction the personnel competency should be developed on. In this study, it is aimed to create a model that can be used to select the correct aircraft system by evaluating all dimensions of the process to decide in which direction the personnel competence should be developed on.

Methodology- Within the scope of this research, one-on-one interviews were conducted, risk analysis and questionnaire were applied. The final priority ranking of the aircraft systems was obtained by using AHP, TOPSIS and VIKOR which are among the MADM methods.

Findings- Research findings have shown that only one parameter cannot be considered for determining the aircraft systems which are important for the development of personnel competency. For selecting the correct aircraft system, all dimensions that show effectiveness of maintenance must be included in the process.

Conclusion- Matching of selected aircraft systems with survey results has been revealed the points that should be emphasized to improve the competence of maintenance staff. This result showed that the developed model can be used with AHP, TOPSIS and VIKOR which are MCDM methods.

Keywords: Aircraft maintenance, competency assessment, AHP, TOPSIS, VIKOR.

JEL Codes: C44, L93, M51

\section{ÇOK BOYUTLU YETKINLIK DEĞERLENDIRMESI: UÇAK BAKIM ORGANIZASYONUNDA BİR UYGULAMA}

\section{ÖZET}

Amaç- Bakım faaliyetlerinin etkinliği ise bakım personelinin yetkinliği ile bağlantılıdır. Farklı operasyonel koşullarda, çeşitli yetkinlik tiplerinde ve karmaşık sistemlere sahip uçaklar üzerinde personel yetkinliğinin hangi yönde geliştirilmesi gerektiğine karar vermek zor bir süreçtir. Bu çalışmada, personel yetkinliğinin hangi yönde geliştirileceğine karar vermek için, sürecin tüm boyutlarını değerlendirerek doğru uçak sistemini seçebilmek amacıyla kullanılabilecek modeli oluşturmak amaçlanmıştır.

Yöntem- Bu araştırma kapsamında birebir görüşmeler yapılmış, risk analizi ve anket uygulanmıştır. ÇKKV yöntemlerinden olan AHP, TOPSIS ve VIKOR'dan faydalanılarak uçak sistemlerinin nihai önem sıralaması elde edilmiştir.

Bulgular- Araştırma bulguları personel yetkinliğinin geliştirilmesi için önemli olan uçak sistemlerinin belirlenmesinde tek bir parametreye bakılamayacağını göstermiştir. Doğru uçak sistemini seçmek için bakımın etkinliğini gösteren tüm boyutların sürece dahil edilmesi gerekmektedir. Sonuç- Önem sırasına göre seçilen uçak sistemleriyle anket sonuçları eşleştirildiğinde elde edilen sonuçlar bakım personelinin yetkinliğini geliştirmek için üzerinde durulması gereken noktaları ortaya çıkarmıştır. Bu sonuç geliştirilen modelin ÇKKV yöntemlerinden AHP, TOPSIS ve VIKOR ile birlikte kullanılabileceğini göstermiştir.

Anahtar Kelimeler: Uçak bakımı, yetkinlik değerlendirme, AHP, TOPSIS, VIKOR.

JEL Kodları: C44, L93, M51 


\section{Giriş}

Ticari uçak üreticileri tasarladıkları her yeni uçak modelinde operasyonel maliyetleri azaltmak ve uçuş emniyetini artırmak amacıyla geliştirmeler yapmaktadır. Bu durum, yeni teknoloji ile tasarlanmış daha kompleks uçak sistemlerini de beraberinde getirmektedir. Uçuş operasyonlarının etkin bir şekilde sürdürülebilmesi için uçak sistemlerinin sorunsuz çalışması beklenmektedir. Ortaya çıkabilecek arızalar uçuş emniyetini etkileyebilir ve kazaya sebep olabilir. Bu nedenle, uçaklarda düzenli olarak bakım yapılmak zorundadır. Bakım, uçak sistemlerindeki sorunların önüne geçmek için yapılmasına rağmen, doğru yapılmayan bakım bu sorunların temel sebebi olabilir. İngiltere Sivil Havacılık Otoritesi tarafından yapılan araştırmalar hava araçlarında karşılaşılan bakım kaynaklı problemlerin önemli bir yeri olduğunu göstermiştir (Civil Aviation Authority [CAA], 2016). Araştırmalar bakım hatalarının uçuş emniyetini ve güvenilirliğini olumsuz olarak etkilediğini net bir şekilde ortaya koymuştur (Marais vd., 2012). Bu sebeple bakım hataları, havayolu işletme maliyetlerini de yükseltmektedir. Hatasız bakım için en temel ihtiyaç yeterli sayıda ve konusunda yetkin bakım personelidir. İhtiyaç duyulan bakım personeli sayısı, yapılması planlanan bakım işi için ihtiyaç duyulacak işgücüne göre kolaylıkla belirlenebilir. Ancak personelin beklenen yetkinliklere sahip olmasını sağlamak çok daha zor süreçlerin tamamlanmasıyla elde edilebilecek bir konudur. Bu yetkinliklerin türü ve önceliği uçak tipi, organizasyon yapısı, uçak tasarım değişiklikleri ve personelin kişisel özellikleri gibi parametrelere bağlı olarak değişkenlik gösterir.

Çalışmanın amacı, uçak bakım organizasyonlarının bakım maliyetlerini azaltabilmek ve uçuş emniyetini artırabilmek amacıyla, organizasyon açısından önemi yüksek uçak sistemlerinin belirlenmesini ve personel yetkinliklerinin bu sistemler bazında ölçülmesini sağlayan modeli oluşturmaktır. Bu sayede, bakım hatalarını minimize edebilmek amacıyla geliştirilmesi gereken personel yetkinlikleri uçak sistemleri bazında belirlenebilecektir. Uçak sistemlerinin önemi belirlenirken Çok Kriterli Karar Verme (ÇKKV) yöntemlerinden yararlanılmıştır.

Çalışma kapsamında ilk olarak uçak bakımının gerekliliği, uçak bakım personelinde olması gereken yetkinlikler ve havacılık sektöründe uygulanan risk analizi incelenmiştir. Uygulama Türkiye' de faaliyet gösteren bir uçak bakım organizasyonunda yapıldığı için, Türkiye Sivil Havacılık Genel Müdürlüğü (SHGM) tarafından kabul edilen standartlar referans alınmıştır. Sonrasında farklı sektörlerdeki ve havacılık sektöründeki ÇKKV problemleri üzerine yapılmış literatür çalışmaları incelenmiştir. Yapılan incelemeler neticesinde araştırma uygulamasının adımları ve kullanılacak ÇKKV yöntemleri belirlenmiştir. Son olarak toplanan veriler ve seçilen ÇKKV yöntemleri kullanılarak bulgular elde edilmiştir.

\section{KURAMSAL TEMELLER VE ILGILI LITERATÜR}

Çalışmanın bu bölümü iki kısımdan oluşmaktadır. Ilk kısım, uçak bakım personeli için gereken yetkinliklerin önemini açıklayabilmek amacıyla, uçak bakımı hakkında bilgiler içermektedir. Uygulama Türkiye'de faaliyet gösteren bir uçak bakım organizasyonunda yapıldığı için, Türkiye'deki uçak bakım sektörünün durumu, SHGM'nin uçak bakım sürecine olan etkisi ve uçak bakım organizasyonlarında yapılması zorunlu olan risk analizi çalışma kapsamına alınmıştır. İkinci kısım, ÇKKV yöntemleri hakkındadır. ÇKKV yöntemleri hakkında bilgiler aktarıldıktan sonra, kullanılacak olan yöntemlerin seçimine katkı sağlamış literatür çalışmaları hakkında bilgiler verilmiştir.

\subsection{Uçak Bakımı ve Uçak Bakım Personelinde Olması Beklenen Yetkinlikler}

Bir hava aracının kullanıcı tarafından kullanım süresi boyunca, yeni, hatasız, çalışır ve temiz bir durumda tutulabilmesi amacıyla, yapılan işlem ve teknik faaliyetlerin tümü 'bakım' olarak adlandırılmaktadır (Mercan, 1999). Bakım, bir şeyi ilk durumuna getirebilmek veya çalışır durumda bulundurabilmek için tadilat, servis, revizyon, durum tespiti ve kontrol gibi birtakım işlemler bütünüdür (Şıktaşlı, 2019). Uçak bakım ve onarım giderleri, direkt işletme giderlerinin yaklaşık \%15-20'sini kapsamaktad. Uçağın kullanım ömrü boyunca yapılan bakımlar için harcanan toplam bakım gideri, uçağın satın alma fiyatının 1-1,5 katı olabilmektedir. Bu nedenlerle bakım maliyetleri operatörlerin işletme giderlerini azaltmak için üzerinde durdukları önemli harcama kalemlerinden birisidir.

Bakım maliyetleri, direkt bakım maliyetleri ve dolaylı bakım maliyetleri olmak üzere iki bölümden oluşmaktadır. Direkt bakım maliyetleri, bir uçak ya da elemanı üzerinde bakım esnasında doğrudan ortaya çıkan işçilik ve malzeme giderlerinin toplamıdır. Dolaylı bakım maliyetleri, bakımın yönetilmesi, kayıtların tutulması ve ekipmanların sağlanması gibi doğrudan işçilik ve malzeme ile ilgili olmayan giderlerin toplamıdır. Bakım personeli tarafından üretilen işgücü etkinliği, personelin eğitimi, bilgisi, becerisi ve tecrübe seviyesi direk bakım maliyetlerine etki eden faktörler arasındadır (Gerede, 1998). Bu sebeple, uçak bakım personelinin yetkinliği direkt bakım maliyetlerini etkileyen önemli bir etkendir. Gerekli yetkinliğe sahip olmayan bakım personeli uçak parçalarının gereksiz olarak sökülmesine, arızaların uzun zamanda giderilmesine, bakım esnasında uçağın hasarlanmasına, gereksiz yedek parça siparişine veya bakımda kullanılan ekipmanların hasarlanmasına sebep olabilir.

Bir uçağın kullanım ve performans limitlerini en iyi bilen o uçağın imalatçısı olduğu için, uçaklara uygulanması gereken bakım işlemlerinin türlerini ve aralıklarını o uçağın imalatçısı belirler. Belirlenmiş bakım türleri ve aralıkları, organizasyonlara uçak 
imalatçısı tarafından her uçak tipi için özel olarak hazırlanmış bir belge aracılığıyla ulaştırılır. Uçak imalatçılarının hazırlamış oldukları bu belge Maintenance Planning Documents (MPD) olarak bilinir. MPD, ilgili uçak tipi için yapılması zorunlu tüm bakım işlemlerinin ve zaman aralıklarının yazılı olduğu bir kaynaktır. İşletmeciler MPD'yi kullanarak kendi bakım programlarını hazırlar ve bağı bulundukları sivil havacılık otoritesine onaylatarak kullanmaya başlarlar (European Union Aviation Safety Agency [EASA], Part-M 2019). MPD'de listelenmiş planlı bakımlar dışında plansız bakım olarak tanımlayabileceğimiz bakım uygulamaları da vardır. Plansız bakımlar, uçuş sırasında uçuş ekibi veya bakım esnasında bakım personeli tarafından saptanan arızalardan kaynaklanmaktadır. Bu arızaların uçuş emniyetini etkilememesi için en kısa süre içinde giderilmesi gerekir. Saptanan arıza hemen giderilemezse imalatçı tarafından hazırlanmış Master Minimum Equipment List (MMEL) olarak bilinen dokümandan faydalanılır. Arıza ile karşılaşılması durumunda bu listeye bakılır. İlgili arıza bu liste içinde bulunuyorsa, uçağın o arıza ile uçuşa gönderilip gönderilemeyeceği hakkında bilgi verir. Illgili arıza bu liste içinde bulunmuyorsa, uçağın o arıza ile uçuşa gönderilemeyeceği kabul edilir. Uçakta bir arıza varken MMEL referansıyla uçağı uçuşa göndermek, ilgili uçağın imalatçısı tarafından kontrol edilen emniyet sınırlarını aşmaz. İmalatçı, bu sınırları belirlemek amacıyla bu kapsamdaki her arıza için kategori belirlemiştir. Kategori A, B, C ve D olarak isimlendirilmiş bu kategoriler, uçağın o arıza ile ne kadar süre uçmaya devam edebileceğini belirler. Kategori $D$ arıza ile 120 gün, kategori C arıza ile 10 gün, kategori $B$ arıza ile 3 gün, kategori $A$ arıza ile 1 gün (bazı istisnalar olabilir) uçak emniyetli bir şekilde uçuşa devam edebilir (EASA, MMEL Manual 2008).

Havacılıkta emniyeti etkileyen faktörlerden birisi olan bakım hataları, diğer faktörlerden farklı olarak saptanması zordur ve uzun süre boyunca uçuş emniyetini etkileme potansiyeline sahiptir (Dalkılıç, 2017). Bakım hataları genellikle uçuş gecikmesi, havada motor durması, uçağın uçuştan çekilmesi, bakımın tekrarlanması, ekipmanlara veya bakım personeline zarar gelmesi gibi olayların arkasındaki gizli sebep olabilir (Liang vd., 2010). Araştırmalar uçak kazalarının tek bir faktör yerine faktör kombinasyonundan kaynaklandığını göstermiştir. Yeterli yetkinliğe sahip olmayan bakım personeli, bu faktörlerden birisidir (Marais vd., 2012). Yetkin bir uçak bakım personeli olmak için tamamlanması gereken birçok süreç vardır. Temel bilgi gerekliliği, tecrübe gerekliliği, iş-başı tecrübesi ve uçak tip eğitimi olarak kategorize edebileceğimiz bu süreçlerin her bakım personeli tarafından tamamlanması zorunludur. Bu süreçlerin temel hedefi, personele uçak bakımında çalışmak için gerekli olan yeterli bilgiyi, beceriyi ve tutumu kazandırmaktır (Dalkılıç, 2017).

Bakım personelinde olması istenen bilgi, beceri ve tutum detaylarıyla havacılık sektörü açısından bağlayıcı olan yayınlarda açıklanmıştır. Bu yayınlar, Türkiye'de Sivil Havacılık Genel Müdürlüğü (SHGM) ve Avrupa'da European Union Aviation Safety Agency (EASA) olarak bilinen sivil havacılık otoriteleri tarafından hazırlanır. Otoriteler bu yayınlarla, hava araçlarında çalışan bakım personeli yetkinliklerini standardize etmeyi amaçlamışlardır. SHGM tarafından bu yayınlar oluşturulurken, havacılık sektöründe Avrupa standartlarını yakalayabilmek amacıyla, EASA referans alınmaktadır.

SHGM tarafından yayınlanan bu yayınlardan SHT-66, Hava Aracı Bakım Personeli Lisans Talimatı olarak bilinir. SHT-66'da bakım personeli olabilmek için tamamlanması gereken eğitim ve tecrübe gereklilikleri detaylarıyla açıklanmıştır. Eğitim ve tecrübe süreçlerini başarılı olarak tamamlayan adaylar, yine aynı talimata göre nihai bir değerlendirmeye tabi tutulurlar. Bu değerlendirmede bakılması gereken bazı temel yetkinlikler vardır. Bu yetkinlikler minimum olarak SHT-66'da listelenmiştir. Bakım organizasyonu işletme politikalarına bağıı olarak bu listeye ilaveler yapabilir ancak listeyi azaltamaz.

SHT-66 talimatına göre oluşturulmuş yetkinlik listesi;

a. Çevre bilinci (Emniyetli hareket et, emniyet önlemlerini uygula ve tehlikeyi önle)

b. Sistem entegrasyonu (Uçak sistemlerini ve sistemlerin etkileşimini anla, bakımı planla ve uygula)

c. Uçak tip bilgisi (Tipe özgü sistemleri bil ve bu sistemler üzerinde emniyetli çalış)

d. Sistem raporları ve sistem göstergeleri (Arıza raporları ve sistem göstergelerini anla ve doğru yorumla)

e. Uçak dokümantasyonunu kullanma ve aradığını bulma (Uygun hava aracı dokümantasyonunu tanımla, tarif edilen bakım prosedürünü bul)

f. Bakım faaliyetlerini gerçekleştirme (Uçak, motor, parça ve aletler üzerinde doğru ve emniyetli bir şekilde çalış)

g. Uçağı uçuşa hazırlama ve bakım kayıtları (Uçağı uçuşa hazırlamak için uygun işlemleri yap, bakım kayıtlarını oluştur)

Bu yetkinlik kriterleri kullanılarak yapılan nihai değerlendirme sonucunda yeterli görülen bakım personeli, uçak üzerinde planlı veya plansız bakımları yapmak üzere yetkilendirilir.

İdeal koşullarda her bir bakım personelinde tüm bu yetkinliklerin bilgi, beceri ve tutum bazında en üst düzeyde ve eşit olması istenir. Ancak gerçek dünyada bunu sağlamak mümkün değildir. Çünkü, her bir personelin kişisel özellikleri ve eğitim altyapısı değişkenlik göstereceği için yetkinlik düzeyleri de farklılaşacaktır. İlave olarak organizasyonun yapısı ve üzerinde çalışılan uçak teknolojisine bağlı olarak, yetkinliklerin önceliği de değişkenlik gösterecektir. Bu sebeple, uçak üzerinde yapılan planlı bakımları, plansız bakımları, karşılaşılan arızaları ve bu arızaların operasyona etkisini uçak sistemleri bazında değerlendirmek ve bakım personelinin bu sistemler üzerindeki yetkinlik düzeyini ölçmek faydalı sonuçlar doğurabilir. Önemi yüksek uçak sistemlerindeki personel yetkinliğini artırmak bakım maliyetlerinin de azalmasını sağlayacaktır. 


\subsection{Uçak Bakımında Risk Analizi ve Risk Değerlendirmesi}

SHGM, sivil havacılık sektöründeki emniyeti korumak amacıyla, havacılık işletmelerindeki emniyet uygulamalarına yönelik açıklamalar içeren SHT-SMS talimatını yayınlamıştır. Uçak bakım organizasyonları, SHT-SMS talimatı gereği, bünyelerinde bağımsız bir emniyet yönetim sistemi oluşturur. Emniyet yönetim sistemi, emniyeti koordineli bir şekilde idare etmek için tüm organizasyon gerekliliklerini karşılayabilecek bir yapıda kurulur. Bu amaçla, organizasyon tarafından sorumlu departman oluşturulur, emniyet politikası ve emniyet hedefleri belirlenir. Sorumlu departman, doğmuş veya doğabilecek tehlikeleri ve risk unsurlarını belirler, söz konusu tehlikeleri ve riskleri bertaraf etmek veya asgari düzeye indirgemek için gerekli faaliyetleri yapar. Bu kapsamda riskleri belirlemek ve değerlendirmek, uçak bakım organizasyonlarındaki her türlü operasyonel süreçte tamamlanması gereken bir aşamadır (SHGM, SHT-SMS 2015)

Risk belirleme süreci kapsamında ilk olarak risk tanımlanır. Riskin tanımlanmasından sonra, riskin taşımakta olduğu zarar ve masraf potansiyelini değerlendirmek için iki boyutlu analiz yapılır. Birinci boyut kötü sonuçlara sebep olabilecek tehlikenin gerçekleşme olasılığıdır. İkinci boyut riskin gerçekleşmesi durumunda ortaya çıkacak etkinin şiddeti veya derecesidir. Bu boyutlar değerlendirilirken 1'den 5'e kadar puanlama yapılır ve Tablo 1'de gösterilmiştir. İki boyutta verilen puanların çarpımı riskin değerini belirler. Bulunan değer kabul edilebilir, gözden geçirilmeli ya da kabul edilmez olarak üç farklı sonuçtan birisini verir.

Tablo 1: Risk analizi nihai değerlendirmesi

\begin{tabular}{|l|c|c|c|c|c|c|}
\hline \multirow{2}{*}{} & \multicolumn{5}{|c|}{ Şiddet } \\
\hline \multirow{2}{*}{ Emniyet Riski } & & Çok Tehlikeli & Tehlikeli & Büyük & Küçük & Ihmal Edilebilir \\
\cline { 3 - 8 } Olasılık & $\mathbf{5}$ & 5 & 4 & 3 & 2 & 1 \\
\hline Sık Görünen & $\mathbf{4}$ & 20 & 16 & 15 & 10 & 5 \\
\hline Ara Sıra Olan & $\mathbf{3}$ & 15 & 12 & 9 & 6 & 4 \\
\hline Pek Az & $\mathbf{2}$ & 10 & 8 & 6 & 4 & 3 \\
\hline Mümkün Görünmeyen & $\mathbf{1}$ & 5 & 4 & 3 & 2 & 2 \\
\hline Pek Mümkün Görünmeyen & & & & & 1 \\
\hline
\end{tabular}

Kaynak: ICAO 9859 - Safety Management Manual, 4. Edition.

Kabul Edilebilir

Gözden Geçirilmeli

Kabul Edilemez

Kabul edilemez olarak değerlendirilen riskler en kısa süre içinde bertaraf edilmek üzere hemen harekete geçilir. Çünkü, bu riskin ortaya çıkma olasılığı yüksek olduğu gibi şiddeti de yüksektir. Gözden geçirilmeli kategorisindeki riskler takip edilir ve süreç içerisinde bertaraf edilmek üzere planlama yapılır. Yapılan planlama riskin hangi kategoriye daha yakın olduğuyla doğrudan ilgilidir. Kabul edilemez kategorisine yakın olan sonuçlar dikkat edilmesi gereken en önemli risk değerlendirme sonuçlarıdır. Kabul edilebilir kategorisindeki riskler için çoğunlukla işlem yapılmaz. Bu değerlendirme bir kez yapıldıktan sonra sonuç kabul edilebilir çıksa bile, zaman içerisinde operasyonel sebepler riskin olasılığını ve şiddetini değiştirebilir. Bu yüzden risk olarak tanımlanan parametreler sürekli olarak takip altında tutulur (SHGM, SHT-SMS 2015).

\section{VERI VE YÖNTEM}

İnsanlar sürekli bir karar verme süreci içerisinde yaşamaktadırlar. Zaman zaman kısa süren, zaman zaman da uzun değerlendirmeler gerektiren bu süreçlerde, çoğunlukla duygusal kararlar vermek suretiyle daha mutlu yaşama arayışı içindedirler. Ancak, işletme yöneticilerinin duygularıyla karar vermesi profesyonel yaşamda pek istenmeyen bir durumdur. Çünkü, yönetimde alınan kararların organizasyon büyüklügüyle orantılı maliyetleri olacaktır. Bu sebeple, yöneticilerden beklenen duygusal karar almak yerine bilimsel yöntemler kullanmalarıdır. Bu ihtiyaca cevap vermek amacıyla karar verme süreçleriyle ilgili olarak yapılmış birçok çalışma literatürde mevcuttur. Bu çalışmalarda karar verme süreci çeşitli şekillerde tanımlanmıştır.

Incel (2019) karar verme işlemini, karar vericinin değişik seçeneklerle karşı karşıya bulunduğu durumlarda, bunlar arasından kendi amaçlarına ve kendisince belirlenmiş ölçütlere ve bu ölçütlerin önemlerine göre en uygun olanı seçebilmesidir olarak ifade etmiştir. Stoner vd., (1989)'a göre karar verme, belirlenen bir amaca yönelik farklı ihtimallerin belirlenmesi ve bunların arasından en etkili olanının seçilmesidir. Zimmermann (2001) çalışmasında, karar ifadesinin kim tarafından kullanıldığına bağlı olarak farklı anlamlar taşıyabileceğini belirtmiştir. Zimmermann'a göre kullanan kişi avukat, iş insanı, asker, psikolog veya istatistikçi olabilir. Bir durumda 
karar, yasal bir ifadeye karşılık gelebilirken, bir başka durumda matematiksel bir değere veya insan davranışına karşılık gelebilir. Karar verme sürecinde seçeneklerin birden fazla kritere sahip olması daha kompleks bir sürecin ortaya çıkmasına sebep olur. Bu zor süreçlerde insanlara doğru karar vermede yardımcı olabilmek amacıyla ÇKKV yöntemleri geliştirilmiştir. Dolan (2008)'e göre bu teknikler, insanların tercihleri ve değerleri ile tutarlı olan daha iyi seçimler yapmalarına yardımcı olmak için özel olarak tasarlanmıştır. ÇKKV yöntemleri, seçeneklerin karar vericiler tarafından belirlenen çoklu kriterlere göre değerlendirilmesine, sıralanmasına ve seçimine olanak sağlayan yöntemlerdir (Çitli, 2006). Bu yöntemler, insan kaynakları yönetimi, üretim planlama, pazarlama, finansal yönetim, yatıım planlama, enerji ve lojistik gibi pek çok alanda etkin olarak uygulanmıştır (Behzadian vd., 2012).

Yapılan literatür araştırmasında ÇKKV yöntemleriyle farklı alanlarda yapılmış birçok çalışma olduğu görülmüştür. ÇKKV yöntemleriyle ilgili havacılık sektöründe uçak bakımında iş emirlerinin okunabilirliği, bakım personelinin performans değerlendirmesi, bakımdaki insan hatalarının değerlendirilmesi, uçak bakım birimlerinin performans değerlendirmesi, uçak bileti ücretinin belirlenmesi, iş yükü stresini etkileyen faktörlerin belirlenmesi, uçak yakıtı türlerinin sürdürülebilirliği, personel seçimi, tedarikçi seçimi, filo planlama optimizasyonu, yolcu uçağı seçimi, servis kalitesine göre en iyi havayolunun belirlenmesi, havayolu performanslarının belirlenmesi ve rota seçimi alanlarında çalışmalar yapılmıştır. Havacılık sektöründe daha önce yapılmış çalışmalar incelendiğinde, ÇKKV yöntemlerinden en fazla kullanılan yöntemlerin AHP ve TOPSIS olduğu görülmüştür (Dozic, 2019). En fazla çalışma yapılmış konu tüketici açısından servis kalitesinin değerlendirilmesidir. Havayolu servis kalitesi üzerine yapılmış literatür çalışmaları incelendiğinde en çok tercih edilen yöntemlerin anket, AHP ve VIKOR olduğu görülmektedir (Perçin, 2018). Uçak bakım alanında yapılmış çalışmaların miktarına bakıldığında, havacılık alanındaki diğer çalışmaların yanında sayıca çok az olduğu görülmüştür (Dozic, 2019).

Bu çalışma kapsamında incelenmiş literatür Tablo 2'de listelenmiştir.

Tablo 2: İncelenmiş Literatür Çalışmaları

\begin{tabular}{|c|c|c|c|c|c|}
\hline Sira & Araştırmacı & Yll & Konu & Kullanılan yöntem & Havacılıkla ilgili mi? \\
\hline 1 & Gökalp ve Soylu & 2010 & Tedarikçi süreçlerini iyileştirme & PROMETHEE & HAYIR \\
\hline 2 & Dinçer ve Görener & 2011 & Performans ölçümü & AHP, VIKOR, TOPSIS & HAYIR \\
\hline 3 & íbicioğlu ve Ünal & 2014 & Yönetici seçimi & AHP & HAYIR \\
\hline 4 & Ertuğrul ve Özçil & 2014 & Klima seçimi & TOPSIS, VIKOR & HAYIR \\
\hline 5 & Kecek ve Yüksel & 2016 & Akıllı telefon seçimi & AHP, PROMETHEE & HAYIR \\
\hline 6 & Karim ve Karmaker & 2016 & Makine seçimi & AHP, TOPSIS & HAYIR \\
\hline 7 & Sadatrasool ve diğ. & 2016 & Yönetici seçimi & AHP, PCA-TOPSIS, VIKOR & HAYIR \\
\hline 8 & İncel & 2019 & Sınıflandırma & Bulanık TOPSIS ve VIKOR & HAYIR \\
\hline 9 & Erçetin & 2019 & Sınıflandırma & AHP & HAYIR \\
\hline 10 & Güneş & 2019 & Hammadde seçimi & AHP, TOPSIS & HAYIR \\
\hline 11 & Büyüktürk & 2019 & Performans ölçümü & TOPSIS, VIKOR, MOORA & HAYIR \\
\hline 12 & Benmoussa ve diğ. & 2019 & Süreç iyileştirme & TOPSIS & HAYIR \\
\hline 13 & Hsia ve diğ. & 2008 & Teknik iş emirlerinin okunabilirliği & AHP & EVET \\
\hline 14 & Wu ve diğ. & 2011 & Performans değerlendirmesi & Bulanık AHP, VIKOR & EVET \\
\hline 15 & Chiu ve Hsieh & 2016 & Süreç iyileştirme & Bulanık TOPSIS & EVET \\
\hline 16 & Jamali ve Khameneh & 2016 & Performans değerlendirmesi & AHP, VIKOR & EVET \\
\hline 17 & Çelik & 2017 & Bilet ücreti optimizasyonu & AHP & EVET \\
\hline 18 & Bongo ve diğ. & 2018 & Süreç iyileştirme & DEMATEL-ANP, & EVET \\
\hline 19 & Chen ve Ren & 2018 & Yakıt türlerinin sürdürülebilirliği & Bulanık ANP ve GRA & EVET \\
\hline 20 & Sofu & 2018 & Personel seçimi & MULTIMOORA, AHP- & EVET \\
\hline 21 & Önen & 2018 & Tedarikçi seçim süreci & AHP & EVET \\
\hline 22 & Dozic ve diğ. & 2018 & Yolcu uçağı seçim süreci & Bulanık AHP & EVET \\
\hline 23 & Gupta & 2018 & Performans değerlendirmesi & VIKOR & EVET \\
\hline
\end{tabular}




\begin{tabular}{|l|l|l|l|l|l|}
\hline 24 & Güntut & 2019 & Filo planlama optimizasyonu & TOPSIS & EVET \\
\hline 25 & Çetinkaya & 2019 & Performans değerlendirmesi & TOPSIS, VIKOR & EVET \\
\hline 26 & Özdemir & 2019 & Yeni rota seçim süreci & AHP & EVET \\
\hline
\end{tabular}

Literatürde en çok tercih edilen ÇKKV yöntemlerinden olması, hesaplama adımlarının basit ve anlaşılır olması, havacılık sektöründeki çalışma sayısının oldukça az olması sebebiyle AHP, TOPSIS ve VIKOR yöntemlerinin bu çalışma kapsamında kullanılması tercih edilmiştir.

Şekil 1: Araştırma Modeli

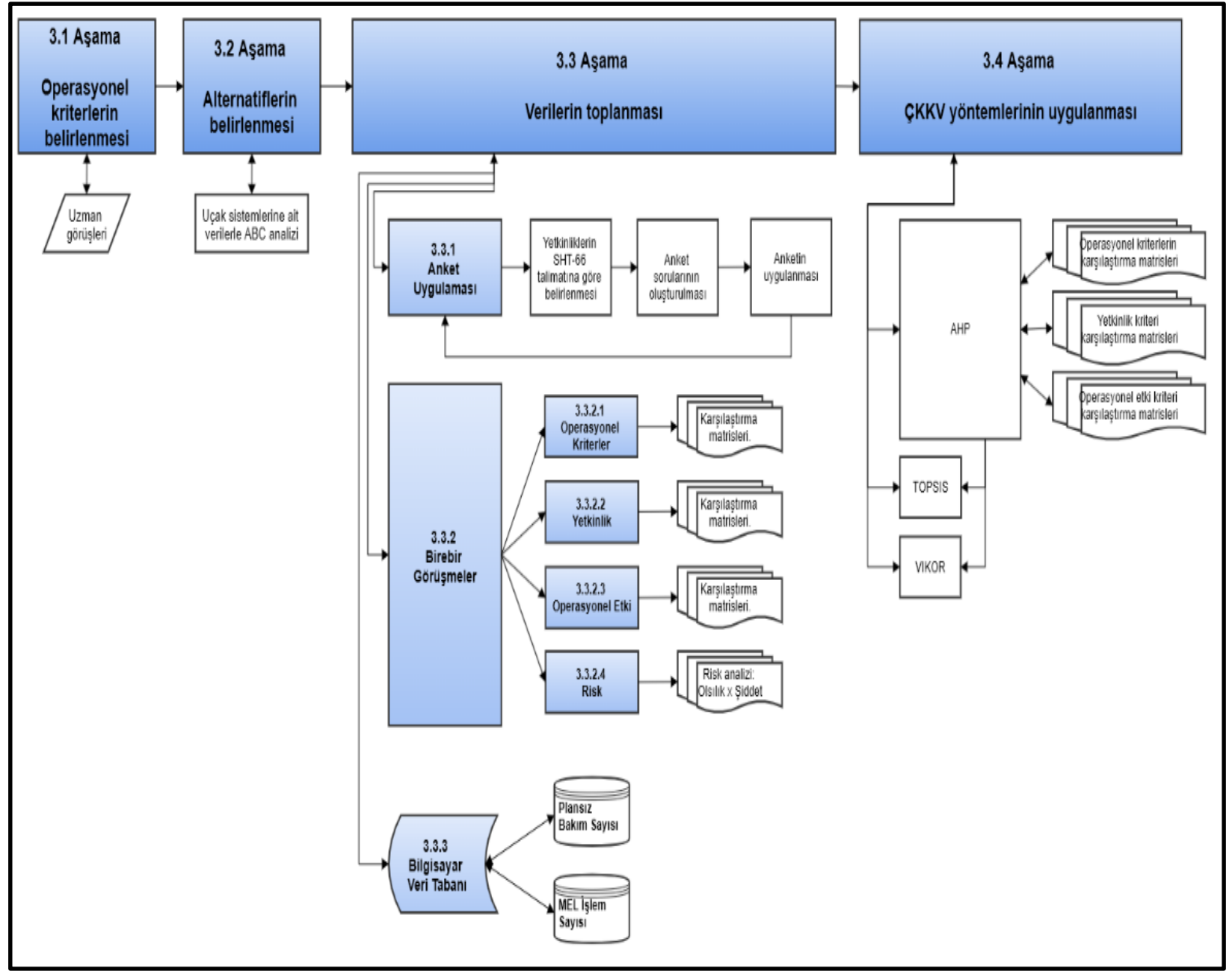

Türkiye'de faaliyet gösteren bir uçak bakım organizasyonunda yapılmış olan ve dört aşamadan oluşan araştırma uygulamasının modeli Şekil 1'de gösterilmiştir. Araştırmanın birinci aşamasında, bakım personelinde olması istenen yetkinliklerle ilişkili ve aynı zamanda bakım maliyetlerinde etkili olan operasyonel kriterler belirlenmiştir. Bu aşamada uzman görüşlerinden faydalanılmıştır. İkinci aşamada, bu kriterlere göre değerlendirilecek alternatif uçak sistemleri $A B C$ analizi yöntemiyle belirlenmiştir. Üçüncü aşamada, kriterlere ve alternatiflere ait verilerin toplanması amaçlanmıştır. Bu amaçla anket uygulanmış, birebir görüşmeler yapılmış ve bilgisayar veri tabanından faydalanılmıştır. Birebir görüşmelerde uzmanlardan alınan veriler kullanılarak AHP yöntemiyle kriterlerin ilk ağılıkları belirlenmiştir. Dördüncü aşamada toplanan veriler kullanılarak AHP-TOPSIS ve AHP-VIKOR yöntemleriyle sonuçlar elde edilmiştir. İlk ağırlıkların TOPSIS ve VIKOR yöntemlerine entegre edilmiş olmasıyla karar vericilerin değerlendirme sürecine katılması sağlanmıştır. AHP-TOPSIS ve AHP-VIKOR yöntemleriyle elde edilen sıralamalar karşılaştırılarak yöntemlerin geçerliliği test edilmiştir. 


\subsection{Operasyonel Kriterlerin Belirlenmesi}

Uçak bakım organizasyonunda yapılan bakım uygulamalarının doğru ve etkin bir şekilde yapılmasından sorumlu olan departman yöneticileriyle kriterlerin belirlenmesi için toplantı yapılmıştır. Yapılan toplantı sonucunda yetkinlik, operasyonel etki, risk, plansız bakım sayısı, MEL işlem sayısı, anket skoru olmak üzere 6 adet kriter belirlenmiştir.

Yetkinlik; Uçak sistemlerinin tasarımında kullanılan yüksek teknoloji bazen kendi arızalarını ekranlarında gösterip kolaylıkla problemin bulunmasına katkı sağlarken, bazen de kompleks yapıları gereği içinden çıkılması neredeyse imkansız arızaları beraberinde getirebilir. Bu yüzden yapılan bakım uygulamaları sistem tasarımına bağlı olarak bazen basit kontrol işlemlerinden ibaret olabilirken, bazen de özel kontrol yöntemlerinin ve ekipmanlarının kullanılmasını gerektirebilir. Örneğin, uçak gösterge sisteminde yapılan bakım uygulamaları çoğunlukla sistem testlerinden oluşmaktadır. Araştırmanın yapıldığı uçak tiplerinde bu testlerin büyük bir bölümü kokpitteki ekranlar üzerinden yapılır. Testlerin başarılı olarak tamamlanması için bakım personelinden beklenen temel olarak sistemin test ekranlarını kullanabilmesi ve bakım el kitaplarındaki iş adımlarını takip edebilmesidir. Testler kokpit içinde uygulandığı için bu testlerin uçak çevresinde çalışması muhtemel diğer kişilere etkileri yoktur. Ancak söz konusu olan sistem uçak hidrolik sistemi olduğunda yapılan bakım uygulamaları gösterge sisteminden farklı olarak çoğunlukla servis ve söküm takım işlemlerinden oluşmaktadır. Ağılıklı olarak kokpit yerine uçak dışında çalışılması gerekir. Servis ve söküm takım işlemlerinin başarılı olarak tamamlanması için bakım personelinden beklenen temel olarak her türlü hava koşullarında çalışabilmesi, gerekli el aletlerini kullanabilmesi ve bakım el kitaplarındaki iş adımlarını takip edebilmesidir. Bu sistem üzerinde çalışırken hidrolik sistemin basınçlandırılması gerektiğinde, uçak çevresinde gerekli emniyet tedbirlerinin doğru bir şekilde alınmış olması şarttır.

Operasyonel Etki; Uçaklarda, sistemlerdeki muhtemel arıza durumunda devreye girecek yedek sistemler veya kullanılacak alternatif yöntemler geliştirilmiştir. Yedek sistemler veya alternatif yöntemler asıl olan sistem arızalandığında devreye girmek üzere tasarlanmıştır. Asıl olan sistemlerdeki arızalar uçuş emniyetini etkileyebilir, uçuş maliyetlerini artırabilir, ilave bakım işlemi gerektirebilir ve plansız olarak karşılaşıldığı için uçuş operasyonlarında istenmeyen aksaklıklara veya gecikmelere sebep olabilir. Örneğin, aydınlatma sistemi temel olarak harici ve dahili olmak üzere iki bölümden oluşmaktadır. Harici aydınlatma uçak çevresinin aydınlatılması için gerekliyken, dahili aydınlatma uçak içinin aydınlatılması için gereklidir. Aydınlatma sisteminde karşılaşılabilecek bir arızanın çoğunlukla operasyonel bir etkisi olmaz. Özellikle gündüz koşullarında zaten havanın aydınlık olması ilave aydınlatmayı kısmen gereksiz kılar. Ancak, pnömatik sistemi uçaklarda kabin basınçlandırma, buz önleme, motor çalıştırma, vb. gibi amaçlarla kullanılmaktadır. Bu sistemde karşılaşılabilecek bir arıza sonucu kabin basınçlandırılamadığında uçuş irtifasında sınırlama, buz önleme sistemi çalıştırılamadığında buzlanma koşullarında uçuş iptali, motor çalıştırma sisteminde problem olduğunda her uçuş öncesinde motor çalıştırmak için ilave servis işlemi gerektirir. Dolayısıyla bu sistem doğrudan operasyonel etkiye sahip olan bir sistemdir.

Risk; Uçaklar hidrolik, yakıt, pnömatik, uçuş kumandaları, göstergeler, elektrik, seyrüsefer, iletişim, vb. gibi birçok farklı sistemin bütünleşik olarak çalışmasıyla emniyetli bir şekilde uçmaktadırlar. Bazı sistemler birçok sistemin doğru çalışması için gerekli verileri, elektrik gücünü, hidrolik gücünü vb. üretirken, bazı sistemler tek başlarına sadece yolcu konforu, acil durum, vb. amaçlarla kullanılmaktadır. Bu sebeple sistemlerde meydana gelebilecek arızalar farklı boyutlardaki riskleri ortaya çıkarırlar. Bazı sistemlerdeki arızalar birçok sistemin çalışmasını bozarak uçuş emniyetini doğrudan etkilerken, bazılarının uçuş emniyetine bir etkisi olmayabilir. Örneğin, uçuş eğlence sistemi yolcu konforunu artırmak amacıyla tasarlanmış bir sistemdir. Uçuş esnasında yolculara uçuşla ilgili bilgiler vermek, tanıtım yapmak ve eğlendirmek amacıyla tasarlanmıştır. Bu sistemde olabilecek bir arızanın uçuş emniyetine çoğunlukla etkisi olmaz. Hatta bazı havayolu firmaları uçuş maliyetlerini azaltmak amacıyla bu sistemi tamamen devre dışı bırakmıştır. Ancak, seyrüsefer sistemi emniyetli uçuş için uçağa ait birçok parametrenin hesaplanması için çalışır. Bu parametrelerin en önemlilerinden olan uçak pozisyonu, uçuş hızı ve uçak konumu seyrüsefer sistemi tarafından hesaplanmaktadır. Bu sistemde ortaya çıkabilecek bir arıza sebebiyle bu parametrelerin hesaplanamaması veya yanlış hesaplanması birçok sistemin çalışmasını olumsuz etkileyerek uçuş emniyetini tehlikeye sokar. Sistemler bazında bu kriterin aldığı değerin yüksek olması, ilgili sistemde karşılaşılabilecek bir arızanın uçuş emniyeti açısından ciddi önem arz ettiğini göstermektedir. Sistemler bazında bu kriterin aldığı değerin düşük olması, ilgili sistemde karşılaşılabilecek bir arızanın uçuş emniyeti açısından pek önem arz etmediğini göstermektedir.

Plansız Bakım Sayısı; Plansız bakımlar çoğunlukla uçak sistemlerinde ortaya çıkan arızalardan kaynaklanmaktadır. Bu bakımların sayısı havayolu açısından maliyetleri etkileyen en önemli faktörlerden birisidir. Çünkü arızanın ne zaman ortaya çıkacağını çoğunlukla öngörmek mümkün olmadığı için, uçuşta ortaya çıkıp plan dışı olarak en yakın havalimanına iniş gerektiren arızalar olabileceği gibi, uçuş öncesi ortaya çıkıp gecikmelere, yolcuların otellere yönlendirilmelerine veya bilet iptallerine sebep olabilir.

MEL İşlem Sayısı; Uçak sistemlerinde karşılaşılan arızalar çözülemediğinde, uçağın bu arıza ile uçuşa gidip gidemeyeceğine karar vermek için MEL dokümanına bakılır. Uçak uçuşa gidecekse kaç gün boyunca hangi koşullar altında uçabileceği yine MEL dokümanı içinde açıklanmıştır. Arızanın çözülememesinin birçok sebebi olabilir. Bakım işlemi için ihtiyaç duyulan zamanın olmaması, yeterli sayıda teknik personelin olmaması, arızanın sebebinin saptanamaması, gerekli parçanın depoda bulunmaması bu sebepler 
arasındadır. Sistemler bazında bu kriterin aldığı değerin yüksek olması, ilgili sistemde arızayla karşılaşılması durumunda çoğunlukla MEL referansıyla uçağın uçuşa gönderildiğini göstermektedir. Sistemler bazında bu kriterin aldığı değerin düşük olması, ilgili sistemde arızayla karşılaşııması durumunda çoğunlukla arızanın uçak uçuşa gitmeden önce giderildiğini göstermektedir.

Bakım personelinin yetkinliği bakımın etkinliği üzerinde doğrudan etkilidir. Yetkin personel, bakım hatalarının az olmasını, gereksiz söküm takım işlemlerinin az olmasını, kısa sürede arızaların giderilmesini hatta bazı arızaların daha ortaya çıkmadan saptanabilmesini sağlayabilir. Bu durumun tam tersi olarak yetkin olmayan personel, bakım hatalarına, gereksiz söküm takım işlemlerine, çözülemeyen arızalara sebep olabilir. Sistemler bazında bu kriterin aldığı değerin yüksek olması, ilgili sistemdeki personel yetkinliğinin yüksek olduğunu göstermektedir. Sistemler bazında bu kriterin aldığı değerin düşük olması, ilgili sistemdeki personel yetkinliğinin düşük olduğunu göstermektedir.

\subsection{Alternatiflerin Belirlenmesi}

Kurumların kaynakları kısıtlı olsa da bu kaynaklarla gerçekleştirilmesi gereken çok sayıda faaliyet söz konusudur. Bu nedenle de kurumlar kaynakların önceliklendirilmesi noktasında etkin bir çaba gösterilmelidir (Çakırkaya vd., 2016). Uçak bakım organizasyonları da sınırlı iş gücü ile birçok uçak sisteminde bakım yapmaktadırlar. Sahip oldukları iş gücünü en çok bakım yapılması gereken sistemleri belirleyerek planlamak etkinliği artıracaktır. Uçak bakım organizasyonlarında pareto analizi yapma gerekliliği de bu sınıflandırmadan doğmaktadır. Pareto analizi 19. yüzyıldan sonra İtalyan economist Vilfredo Pareto (1848-1923) tarafından isimlendirilmiş olup değerin nerede olduğunu vurgulayan bir analiz tekniğidir. Bu yöntem, "ABC analizi", "80/20 kuralı" veya "Pareto analizi" olarak bilinmektedir. Literatür incelendiğinde, bu analiz yönteminin birçok sektörde başarılı olarak kullanıldığı görülmüştür (Çakırkaya vd., 2016). Uçak bakım organizasyonu için, uçak sistemlerinde uygulanabilecek pareto analizi aşağıdaki altı adım kullanılarak gerçekleştirilebilir.

1. Bakımların Listelenmesi: Belirli bir zaman aralığında uygulanmış tüm plansız bakım işleri listelenir.

2. Sistem Bazında Ölçüm: Oluşturulmuş liste kullanılarak her bir uçak sistemindeki plansız bakım sayısı hesaplanır.

3. Sıralama: Uçak sistemleri, gerçekleştirilmiş plansız bakım sayısına göre büyükten küçüğe sıralanır.

4. Kümülatif Dağılımların Hesaplanması: Her bir uçak sisteminin toplam içindeki yüzdesi bulunur. Ardından bu yüzdelerin kümülatif toplamları hesaplanır.

5. Grafiğin Çizimi: Uçak sistemleri yatay eksene eşit aralıklarla ve önem derecelerine göre sütunlar halinde yerleştirilir. En çok bakım işine sahip uçak sistemini temsil eden sütun en sola yerleştirilir. Sağa doğru ise bakım sayıları gittikçe azalan sistemleri temsil eden sütunlar yer almaktadır. Örnek grafik Şekil 2'de gösterilmiştir.

6. Grafiğin Yorumu: Pareto grafiği, dikkat ve çabanın daha önemli uçak sistemleri üzerine yoğunlaşmasını sağlar. Grafiğe göre en soldaki uçak sistemi üzerinde çalışmak daha büyük etki sağlayabilir. Ancak, dikkat edilmesi gereken en önemli husus, en önemli uçak sistemi her zaman en soldaki değildir. Çünkü sistemlerin bakım sayısı az olsa bile operasyonel kriterler bazında değerlendirildiğinde sağdaki uçak sistemleri daha önemli hale gelebilir.

Şekil 2: Uçak Sistemlerinde Örnek ABC Analizi Modeli

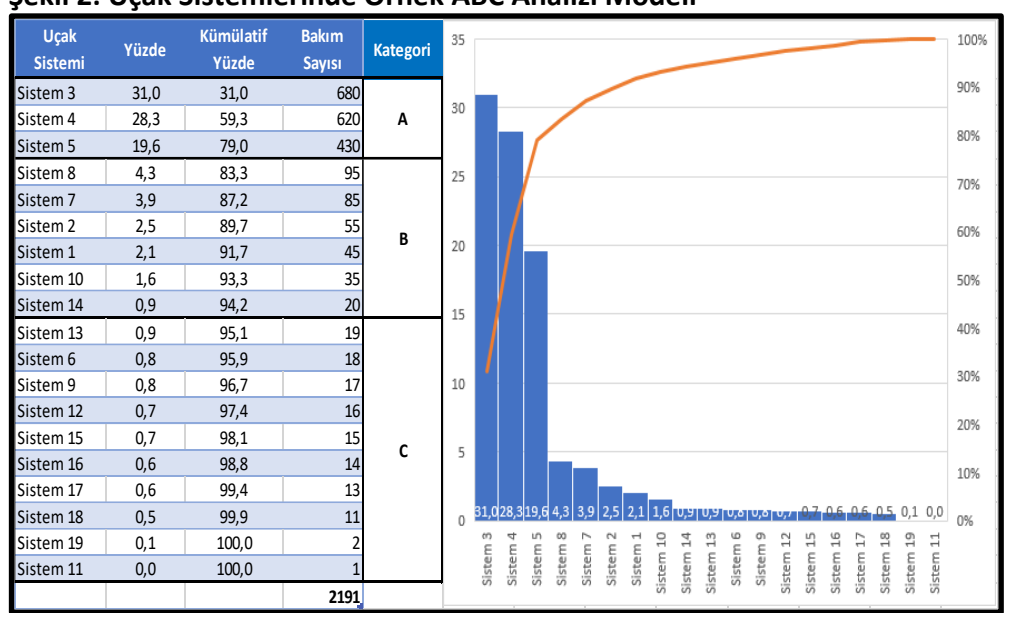

Altı adımın tamamlanmasından sonra toplam bakım işlerinin yüzde 80'ine isabet eden en önemli uçak sistemleri kategori $A$, toplam bakım işlerinin yüzde $15^{\prime}$ ine isabet eden en önemli uçak sistemleri kategori $B$, toplam bakım işlerinin yüzde $5^{\prime}$ ine isabet eden en önemli uçak sistemleri kategori C olarak sınıflandırılır. 


\subsection{Verilerin Toplanmasi}

Araştırmada kullanılan veriler üç farklı yöntemle temin edilmiştir.

a. Anket Uygulaması: Bakım personelinin yetkinlik seviyesini ölçmek amacıyla yetkinlik kriterleriyle ilişkili anket soruları hazırlanmış ve tüm alternatif sistemleri bu kriterler üzerinden değerlendirebilmek amacıyla anket uygulanmıştır.

b. Birebir görüşmeler: Araştırmanın yapıldığı organizasyonda teknik departman yöneticileriyle birebir görüşmeler yapılmıştır. Bu görüşmelerde ilk olarak AHP yardımıyla operasyonel kriterlerin ağırlıkları belirlenmiştir. Sonrasında yine AHP yardımıyla yetkinlik ve operasyonel etki kriterlerinin ağırlıkları belirlenmiştir. Son olarak risk analizi yaparak alternatif sistemlerin riski belirlenmiştir.

c. Bilgisayar veri tabanı: Uçak bakım kayıtlarının tutulduğu veri tabanından faydalanılarak her bir alternatif sistem bazında organizasyonda uygulanmış plansız bakım sayısı ve MEL işlem sayısı belirlenmiştir.

ABC analizi ile belirlenmiş olan sistemler bazında personel yetkinliğini ölçebilmek için, SHGM SHT-66 talimatındaki yetkinlik listesi kullanılarak anket oluşturulmuştur. Oluşturulan ankette kullanılan sorular sistem bazlı yetkinlik ve genel mesleki yetkinlik olmak üzere iki kategoride toplanmıştır. 5li likert ölçeği kullanılarak hazırlanmış olan anket araştırmanın yapılacağı uçak bakım organizasyonunda çalışan uçak bakım personeline birebir görüşme yöntemiyle uygulanmıştır. Ankete katılım için katılımcılarda hava aracı bakım lisansına sahip olması ve bakım organizasyonunda bakımı yapılan uçak tiplerinde yetkili olması şartı aranmıştır. Sistem bazlı yetkinlik soruları aynı kişi için her sistemde farklılık gösterebilecek yetkinlikleri ölçmek amacıyla hazırlanmıştır. Örneğin sistem etkileşimi, uçak tipi ve sistemi değiştikçe değişebilecek bir yetkinliktir. Bir kişi aynı zamanda bir uçak sisteminin etkileşimi hakkında çok iyi düzeyde bilgi sahibi olmasına rağmen, bir başka uçak sistemi hakkında yeterli bilgiye sahip olmayabilir. Bu yüzden, bu soru her alternatif sistem için ayrı ayrı sorulmuştur. Bu kategoride belirlenen sorular şunlardır;

a. Sistemin diğer sistemlerle etkileşimini anlarım, bakımı planlar ve uygularım

b. Sistem arıza raporlarını/göstergelerini anlarım ve doğru yorumlarım

c. Sistem detayları hakkında yeterli bilgiye sahibim

d. Emniyetli hareket ederim, emniyet önlemlerini uygular ve tehlikeyi önlerim

e. Güncel bakım el kitaplarına göre doğru çalışırım

Genel mesleki yetkinlik soruları sistemlerden bağımsız olan yetkinlikleri ölçmek amacıyla hazırlanmıştır. Bu kategoride belirlenen sorular şunlardır;

a. Güncel ve doğru dokümantasyonu bilirim, tarif edilen bakım prosedürünü bulurum

b. Uçağı uçuşa hazırlamak için uygun işlemleri yaparım, bakım kayıtlarını oluştururum

Araştırmanın yapıldığı organizasyonda çalışan sektör deneyimine sahip teknik departman yöneticileri uzman karar vericiler olarak belirlenmiştir. Görüşmeler esnasında ilk olarak araştırmada kullanılacak metotlar ve sayısal teknikler izah edilmiştir. Görüşmeler esnasında elde edilen verilerin toplanması için Excel programı kullanılmıştır. Yapılan birebir görüşmelerde operasyonel kriterler, yetkinlik, operasyonel etki ve risk olmak üzere 4 konu başlığında çalışma yapılmıştır. Operasyonel kriterler, yetkinlik ve operasyonel etki kriterlerinin ağılıklarını belirlemek amacıyla AHP yöntemi kullanılmıştır. Excel yazılımı kullanılarak hazırlanmış olan karşılaştırma matrisi görüşmeler esnasında uzman karar vericilerle birlikte doldurulmuş ve anlık olarak tutarlılık indeksinin hesaplanmasıyla karar vericilerin kararlarında değişiklik yapmalarına imkan sağlanmıştır. Görüşmelerde kullanılan tablo örneği Şekil 3'de gösterilmiştir. Karar vericilerden ayrı ayrı elde edilen ağırlıkların grup kararına dönüştürülmesi için verilerin geometrik ortalaması alınmıştır.

Şekil 3: Operasyonel Kriterler Karşılaştırma Örneği

\begin{tabular}{|c|c|c|c|c|c|c|c|c|c|c|c|c|c|c|c|c|c|c|c|c|c|c|c|c|c|c|c|}
\hline \multicolumn{20}{|c|}{ OPERASYONEL KRITERLERIN KARŞILAŞTIRILMASı (Lütfen ilgili kutucuğa $X$ yazın) } & \multicolumn{8}{|c|}{ OPERASYONEL KRITERLERIN KARŞILAŞTIRILMASI } \\
\hline \multirow[t]{2}{*}{ No } & \multirow[t]{2}{*}{ KRITER } & \multicolumn{8}{|c|}{ SOL KRITERIN ÖNEMI FAZLA } & \multirow{2}{*}{$\begin{array}{c}\begin{array}{c}\text { ESSiT } \\
\text { ÓNEM }\end{array} \\
1\end{array}$} & \multicolumn{8}{|c|}{ SAĞ KRITERIN ÖNEMI FAZLA } & \multirow[t]{2}{*}{ KRITER } & & 1 & 2 & 3 & 4 & 5 & 6 & w \\
\hline & & 9 & 8 & 7 & 6 & 5 & 4 & 3 & 2 & & 2 & 3 & 4 & 5 & 6 & 7 & 8 & 9 & & 1 & 1,00 & 3,00 & 2,00 & 0,50 & 0,33 & 0,33 & 0,1277 \\
\hline $1 \mathrm{~A}$ & Yetkinlik & & & & & & & $x$ & & & & & & & & & & & Anket Skoru & 2 & 0,33 & 1,00 & 1,00 & 0,50 & 0,33 & 0,33 & 0,0779 \\
\hline $1 \mathrm{~B}$ & Yetkinlik & & & & & & & & $x$ & & & & & & & & & & Operasyonel Etki & 3 & 0,50 & 1,00 & 1,00 & 0,33 & 0,33 & 0,33 & 0,0724 \\
\hline $1 \mathrm{C}$ & Yetkinlik & & & & & & & & & & $x$ & & & & & & & & Risk & 4 & 2,00 & 2,00 & 3,00 & 1,00 & 2,00 & $|2,00|$ & \begin{tabular}{|l|l|}
0,2776 \\
\end{tabular} \\
\hline 10 & Yetkinlik & & & & & & & & & & & $x$ & & & & & & & Plansız Bakım Sayısı & 5 & 3,00 & 3,00 & 3,00 & 0,50 & 1,00 & 2,00 & 0,2454 \\
\hline $1 \mathrm{E}$ & Yetkinlik & & & & & & & & & & & $x$ & & & & & & & MEL işlem Sayısı & 6 & 3,00 & 3,00 & 3,00 & 0,50 & 0,50 & 1,00 & 0,1991 \\
\hline $2 \mathrm{~A}$ & Anket Skoru & & & & & & & & & $x$ & & & & & & & & & Operasyonel Etki & Top & 9,83 & 13,00 & 13,00 & $3, \mathbf{3 3}$ & 4,50 & 6,600 & 1,00 \\
\hline $2 \mathrm{~B}$ & Anket Skoru & & & & & & & & & & $\mathrm{x}$ & & & & & & & & Risk & & & & & & & & \\
\hline $2 \mathrm{C}$ & Anket Skoru & & & & & & & & & & & $x$ & & & & & & & Plansız Bakım Sayısı & & & & & & & & \\
\hline $2 \mathrm{D}$ & Anket Skoru & & & & & & & & & & & $x$ & & & & & & & MEL İşlem Sayısı & & & & SONUC & TABLC & & & \\
\hline 3A & Operasyonel Etki & & & & & & & & & & & $x$ & & & & & & & Risk & 1 & Yetki & kinlik & & & & 0,1277 & \\
\hline 3в & Operasyonel Etki & & & & & & & & & & & $x$ & & & & & & & Plansız Bakım Sayısı & 2 & Anke & et Skor & & & & 0,0779 & \\
\hline $3 \mathrm{C}$ & Operasyonel Etki & & & & & & & & & & & $x$ & & & & & & & MEL isslem Sayısı & 3 & Oper & rasyon & lel Etki & & & 0,0724 & \\
\hline 4A & Risk & & & & & & & & $x$ & & & & & & & & & & Plansız Bakım Sayısı & 4 & Risk & & & & & 0,2776 & \\
\hline $4 \mathrm{~B}$ & Risk & & & & & & & & $x$ & & & & & & & & & & MEL isslem Sayısı & 5 & Plan: & siz Bakı & im Sayıs & & & 0,2454 & \\
\hline $5 \mathrm{~A}$ & Plansız Bakım Sayısı & & & & & & & & $x$ & & & & & & & & & & MEL isslem Sayısı & 6 & MEL & işlem s & Sayısı & & & 0,1991 & \\
\hline
\end{tabular}


Sistemlerin riskini belirlemek için karar vericilerle birebir görüşme yapılmış ve risk analizi uygulanmıştır. Excel yazılımı kullanılarak hazırlanmış olan tablo görüşmeler esnasında uzman karar vericilerle birlikte doldurulmuştur. Görüşmelerde kullanılan tablo örneği Şekil 4'de gösterilmiştir. Karar vericilerden ayrı ayrı elde edilen ağırlıkların grup kararına dönüştürülmesi için verilerin geometrik ortalaması alınmıştır.

\section{Şekil 4: Risk Belirleme}

\begin{tabular}{|c|c|c|c|c|c|c|c|c|c|c|c|c|c|c|}
\hline \multicolumn{2}{|r|}{ RisK ANALizi } & \multicolumn{5}{|c|}{ ŞIDDET } & \multicolumn{5}{|c|}{ OLASILIK } & \multirow[b]{2}{*}{ SONUÇ } & \multicolumn{2}{|c|}{ Muhtemel sistem arızasının şiddeti. } \\
\hline SIRA & SISTEM & 1 & 2 & 3 & 4 & 5 & 1 & 2 & 3 & 4 & 5 & & Şiddet & \\
\hline A & 33 - Aydınlatma & $\mathrm{x}$ & & & & & & & & & $\bar{x}$ & 5 & 5 & Çok Tehlikeli \\
\hline B & 32 - İniş Takımları & & & $x$ & & & & $x$ & & & & 6 & 4 & Tehlikeli \\
\hline c & 70 - Motor & & & & $\mathrm{x}$ & & & & $x$ & & & 12 & 3 & Büyük \\
\hline D & 35 - Oksijen & & $\mathrm{x}$ & & & & & $x$ & & & & 4 & 2 & Küçük \\
\hline E & 34 - Seyrüsefer & $x$ & & & & & & & $x$ & & & 3 & 1 & Inmal Edilebilir \\
\hline$F$ & 21 - Iklimlendirme & & $x$ & & & & & & & $x$ & & 8 & \multicolumn{2}{|c|}{ Sistemde arıza olma olasıı̆ı̆ı. } \\
\hline G & 23 - Iletiş̧im & & $x$ & & & & & & $x$ & & & 6 & Olasilık & \\
\hline H & 31 - Göstergeler ve Kayıt & & $x$ & & & & & & $x$ & & & 6 & 5 & Sık Görünen \\
\hline $\mathrm{J}$ & 27 - Uçuş Kumandaları & & & $\mathrm{x}$ & & & & $x$ & & & & 6 & 4 & Ara Sira Olan \\
\hline K & 38 - Su ve Atık Su & $x$ & & & & & & & & $x$ & & 4 & 3 & Pek Az \\
\hline $\mathbf{L}$ & 30 - Buz ve Yağmur Önleme & & & $x$ & & & & & $x$ & & & 9 & 2 & Mümkün Görünmeyen \\
\hline$M$ & 28 - Yakıt & & $\mathrm{x}$ & & & & & $x$ & & & & 4 & 1 & Pek Mümkün Görünmeyen \\
\hline N & 36 - Pnömatik & & & $\mathrm{x}$ & & & & & $x$ & & & 9 & & \\
\hline 0 & 22 - Otomatik Uçuş & & & $\mathrm{x}$ & & & & $x$ & & & & 6 & & \\
\hline $\mathbf{P}$ & 29 - Hidrolik Gücü & & & $\mathrm{x}$ & & & & & $x$ & & & 9 & & \\
\hline
\end{tabular}

Araştırmanın yapıldığı organizasyonda gerçekleştirilmiş tüm uçak bakım işlemleri, uçak üreticilerinin belirlediği numaralandırma sistemine göre gruplandırılarak, merkezi bilgisayar sistemine bağlı veri tabanına kaydedilmektedir. Kayıtlarda, her bir bakım işlemi için, bakımın uygulandığı uçak, bakım işinin türü, bakım için harcanan zaman, vb. tüm bilgiler saklanmaktadır. Araştırma kapsamında belirlenmiş olan alternatif uçak sistemlerine ait son 5 yılda gerçekleştirilmiş bakım verileri bu veri tabanı kullanılarak elde edilmiştir.

\section{UYGULAMA}

Araştırma kapsamında AHP, TOPSIS ve VIKOR yöntemleri kullanılmıştır. Karar vericilerin fikirleri AHP yöntemi ile araştırma sürecine dahil edilmiştir. Bilgisayar veri tabanından elde edilen sayısal değerler ve anket sonuçları ile AHP ile elde edilmiş veriler TOPSIS ve VIKOR yöntemleri kullanılarak işlenmiştir.

Adım 1 - Karşılaştırmalar yapılırken $a_{12}$, 1. kriter ile 2. kriter arasındaki ikili karşılaştırma değeri, $a_{21}$ ise 2 . kriter ile 1 . kriter arasındaki ikili karşılaştırma değerini temsil ettiği durumda;

$$
a_{12}=1 / a_{21}
$$

Adım 2 - Kriterlerin kendi aralarında karşılaştırılmasına yönelik örnek matris 3.2 numaralı denklemde gösterilmiştir. Bu karşılaştırmalar yapılırken kriterin kendisi ile kıyaslanması durumunda sonuç 1 olacağı için denklem 3.2'deki örnek matriste verilmiş $a_{11}, a_{22}, a_{33}, \ldots, a_{n n}$ değerleri 1 'dir. Hesaplamalarda kullanılan " $n$ " sembolü karşılaştırılan birimlerin sayısını ifade etmektedir.

$$
A_{n \times n}=\left[\begin{array}{cccc}
a_{11} & a_{12} & \ldots & a_{1 \mathrm{n}} \\
a_{21} & a_{22} & \ldots & a_{2 \mathrm{n}} \\
\ldots & \ldots & \ldots & \ldots \\
a_{n 1} & a_{n 2} & \ldots & a_{n n}
\end{array}\right]
$$

Adım 3 - Oluşturulmuş her ikili karşılaştırma matrisi için önem düzeyi hesaplanır. Önem düzeyinin bulunması için üç aşamalı hesaplama yapılması gerekir.

Adım 3.1 - İlk olarak her sütundaki değerler toplanır.

$$
\sum_{i=1}^{n} a_{i 1} \quad \sum_{i=1}^{n} a_{i 2} \quad \ldots \quad \sum_{i=1}^{n} a_{i n}
$$

Adım 3.2 - Karşılaştırma matrisindeki her eleman ait olduğu sütunun toplamına bölünür. 


$$
A_{n \times n}=\left[\begin{array}{cccc}
\frac{a_{11}}{\sum_{i=1}^{n} a_{i 1}} & \frac{a_{12}}{\sum_{i=1}^{n} a_{i 2}} & \ldots & \frac{a_{1 n}}{\sum_{i=1}^{n} a_{i n}} \\
\frac{a_{21}}{\sum_{i=1}^{n} a_{i 1}} & \frac{a_{22}}{\sum_{i=1}^{n} a_{i 2}} & \ldots & \frac{a_{2 n}}{\sum_{i=1}^{n} a_{i n}} \\
\ldots & \ldots & \ldots & \ldots \\
\frac{a_{n 1}}{\sum_{i=1}^{n} a_{i 1}} & \frac{a_{n 2}}{\sum_{i=1}^{n} a_{i 2}} & \ldots & \frac{a_{n n}}{\sum_{i=1}^{n} a_{i n}}
\end{array}\right]
$$

Adım 3.3 - Her satırdaki elemanların ortalaması hesaplanır. Bulunan $W$ değerleri ilgili alternatiflerin önem düzeyleridir. Önem düzeyi en yüksek olan alternatif istenen amaca en yakın sonucu verir. Her alternatif için önem düzeyi şu şekilde hesaplanır.

$$
\begin{aligned}
& W_{11}=\frac{\frac{a_{11}}{\sum_{i=1}^{n} a_{i 1}}+\frac{a_{12}}{\sum_{i=1}^{n} a_{i 2}}+\ldots+\frac{a_{1 n}}{\sum_{i=1}^{n} a_{i n}}}{n} \\
& W_{21}=\frac{\frac{a_{21}}{\sum_{i=1}^{n} a_{i 1}}+\frac{a_{22}}{\sum_{\mathrm{i}=1}^{n} a_{i 2}}+\ldots+\frac{a_{2 n}}{\sum_{i=1}^{n} a_{i n}}}{n} \\
& \ldots \\
& W_{n 1}=\frac{\frac{a_{n 1}}{\sum_{i=1}^{n} a_{i 1}}+\frac{a_{n 2}}{\sum_{i=1}^{n} a_{i 2}}+\ldots+\frac{a_{n n}}{\sum_{i=1}^{n} a_{i n}}}{n}
\end{aligned}
$$

Adım 4 - Tutarlıık oranı hesaplanır. Bu hesaplama dört aşamalı olarak gerçekleştirilir.

Adım 4.1 - Ağırlıklı toplam vektör değerleri hesaplanır.

$$
\sum_{i=1}^{n}\left(w_{i 1} \cdot\left[\begin{array}{c}
a_{1 i} \\
a_{2 i} \\
\ldots \\
a_{n i}
\end{array}\right]\right)=\left[\begin{array}{c}
W S_{11} \\
W S_{21} \\
\ldots \\
W S_{n 1}
\end{array}\right]
$$

Adım 4.2 - $\lambda_{\max }$ değeri hesaplanır.

$$
\lambda_{\max }=\frac{\sum_{i=1}^{n} \frac{W s_{i 1}}{W_{i 1}}}{n}
$$

Adım 4.3 - CI olarak ifade edilen tutarlılık indeksi hesaplanır.

$$
C I=\frac{\lambda_{\max }-n}{n-1}
$$

Adım 4.4 - $C R$ olarak ifade edilen tutarlılı oranı hesaplanır. Bu hesaplamada " $R I$ " değeri, rassal indeks olarak bilinen ve karşılaştırma matrisinden rassal olarak üretilen tutarlııı indeksidir. Bu değer karşılaştırma yapılan ölçüt ya da alternatif sayısına bağı olarak farklı değerler alır. Rassal indeksin hesaplanmasıyla ilgili birçok çalışma yapılmıştır. Bu çalışmalarda farklı sonuçlar elde edilmesine rağmen Saaty, Golden ve Wang, Lane ve Verdini, ve Forman tarafından yapılan çalışmalarda birbirine çok yakın rassal indeks değerleri bulunmuştur (Tummala vd., 1998). Bu sebeple Golden ve Wang tarafından yapılan hesaplamanın sonucunda bulunan rassal indeks değerleri bu çalışmanın hesaplamalarında kullanılmıştır.

$$
C R=\frac{C I}{R I}
$$

Adım 5 - Yapılan her ikili karşılaştırmanın tutarlı kabul edilebilmesi için hesaplanan $C R$ değeri aşağıdaki koşulu sağlamalıdır (Tummala vd., 1998).

$$
C R \leq 0.10
$$

TOPSIS ile karar verme probleminin çözümü altı adımdan oluşmaktadır. Her adımda yapılan işlemler örnek matris ile desteklenerek açıklanmıştır. Örnek matriste kullanılan $X$ sembolü alternatifi, $m$ sembolü alternatif sayısını, $p$ sembolü de kriter sayısını, $a$ sembolü ilgili kriterler için alternatiflerin aldığı değerleri ifade etmektedir. 
Adım 1 - Karar matrisi oluşturulur.

$X_{i j}=\left[\begin{array}{cccc}a_{11} & a_{12} & \ldots & a_{1 p} \\ a_{21} & a_{22} & \ldots & a_{2 p} \\ a_{31} & a_{32} & \ldots & a_{3 p} \\ \ldots & \ldots & \ldots & \ldots \\ a_{m 1} & a_{m 2} & \ldots & a_{m p}\end{array}\right]$

Adım 2 - Karar matrisi üzerinde normalizasyon işlemi yapılır. Literatürdeki çalışmalarda kullanılmış birden fazla normalizasyon yöntemi vardır. En çok kullanılanın vektör normalizasyonu olduğu görülmüştür. Bu sebeple bu çalışmada vektör normalizasyonu kullanılmıştır. Vektör normalizasyonu 3.14 denkleminde gösterildiği gibi yapılır.

$$
N_{i j}=\frac{a_{i j}}{\sqrt{\sum_{i=1}^{m} a_{i j}^{2}}},(i=1,2, \ldots, m ; j=1,2, \ldots, p)
$$

Normalizasyon yapıldıktan sonra elde edilen örnek normalize edilmiş matris 3.15 numaralı denklemde verilmiştir.

$$
N_{i j}=\left[\begin{array}{cccc}
n_{11} & n_{12} & \ldots & n_{1 p} \\
n_{21} & n_{22} & \ldots & n_{2 p} \\
n_{31} & n_{32} & \ldots & n_{3 p} \\
\ldots & \ldots & \ldots & \ldots \\
n_{m 1} & n_{m 2} & \ldots & n_{m p}
\end{array}\right]
$$

Adım 3 - Ağırlıklandırılmış normalize edilmiş matris oluşturulur. Bu matrisin oluşturulması için 3.16 numaralı örnek matriste gösterildiği gibi kriterlerin ağılıklarıyla her bir alternatife ait normalize edilmiş değerler çarpılır. 3.16 numaralı denklemdeki örnek matriste kullanıımış olan $w$ değerleri kriter ağırlıklarını göstermektedir.

$$
V_{i j}=\left[\begin{array}{cccc}
w_{1} \cdot n_{11} & w_{2} \cdot n_{12} & \ldots & w_{p} \cdot n_{1 p} \\
w_{1} \cdot n_{21} & w_{2} \cdot n_{22} & \ldots & w_{p} \cdot n_{2 p} \\
w_{1} \cdot n_{31} & w_{2} \cdot n_{32} & \ldots & w_{p} \cdot n_{3 p} \\
\ldots & \ldots & \ldots & \ldots \\
w_{1} \cdot n_{m 1} & w_{2} \cdot n_{m 2} & \ldots & w_{p} \cdot n_{m p}
\end{array}\right] \Rightarrow V_{i j}=\left[\begin{array}{cccc}
v_{11} & v_{12} & \ldots & v_{1 p} \\
v_{21} & v_{22} & \ldots & v_{2 p} \\
v_{31} & v_{32} & \ldots & v_{3 p} \\
\ldots & \ldots & \ldots & \ldots \\
v_{m 1} & v_{m 2} & \ldots & v_{m p}
\end{array}\right]
$$

Adım 4 - İdeal $\left(A^{*}\right)$ ve negatif ideal $\left(A^{-}\right)$çözüm setleri oluşturulur. İdeal $\left(A^{*}\right)$ çözüm seti her bir kriter için, ilgili kriterin minimum olması isteniyorsa kriter değerlerinin en küçüğü, ilgili kriterin maksimum olması isteniyorsa kriter değerlerinin en büyüğü seçilerek oluşturulur.

$$
A^{*}=\left\{\left(\max _{i} v_{i j} \mid j \in J\right),\left(\min _{i} v_{i j} \mid j \in J^{\prime}\right)\right\} \Rightarrow A^{*}=\left\{v_{1}, v_{2}, \ldots, v_{n}\right\}
$$

Negatif ideal $\left(A^{-}\right)$çözüm seti her bir kriter için, ilgili kriterin minimum olması isteniyorsa kriter değerlerinin en büyüğü, ilgili kriterin maksimum olması isteniyorsa kriter değerlerinin en küçüğü seçilerek oluşturulur.

$$
A^{-}=\left\{\left(\min _{i} \quad v_{i j} \mid j \in J\right) \quad,\left(\max _{i} \quad v_{i j} \mid j \in J^{\prime}\right)\right\} \Rightarrow A^{-}=\left\{v_{1}, v_{2}, \ldots, v_{n}\right\}
$$

Adım 5 - İdeal $\left(A^{*}\right)$ ve negatif ideal $\left(A^{-}\right)$noktalara olan uzaklık değerleri hesaplanır. Bu aşamada, 3.adımda elde edilmiş olan ağırlıklandırılmış normalize edilmiş matris $\left(V_{i j}\right)$ değerlerinin ideal $\left(A^{*}\right)$ ve negatif ideal $\left(A^{-}\right)$çözüm setindeki noktalara olan öklit uzaklık değerleri hesaplanır. İdeal çözüm setine olan uzaklık $S_{i}^{*}$, negatif ideal çözüm setine olan uzaklık ise $S_{i}^{-}$olarak adlandırılmaktadır.

İdeal Uzaklık

$$
\begin{aligned}
& S_{i}^{*}=\sqrt{\sum_{j=1}^{n}\left(v_{i j}-v_{j}^{*}\right)^{2}} \\
& S_{i}^{-}=\sqrt{\sum_{j=1}^{n}\left(v_{i j}-v_{j}^{-}\right)^{2}}
\end{aligned}
$$

Adım 6 - İdeal çözüme göreli yakınlık hesaplanır. Her bir alternatifin ideal çözüme göreceli yakınlığının hesaplanmasında 3.21 numaralı denklem kullanılır. Buradaki $C_{i}^{*}$ değeri $0 \leq C_{i}^{*} \leq 1$ aralığında değer alır. Bu değerin 1 olması ilgili alternatifin ideal çözüm noktasında olduğunu, bu değerin 0 olması ilgili alternatifin negatif ideal çözüm noktasında olduğunu gösterir.

$$
C_{i}^{*}=\frac{s_{i}^{-}}{s_{i}^{-}+s_{i}^{*}}
$$

Bu altı adımın tamamlanmasıyla elde edilecek $C_{i}^{*}$ değerlerinin en büyüğü amaca en uygun alternatifi göstermektedir. Bu değerlere göre yapılacak sıralama tercih sırası olarak ifade edilir. 
VIKOR yöntemi ile karar verme probleminin çözümünde aşağıdaki aşamalar uygulanır. Çözüm aşamalarında kullanılan $m$ sembolü alternatif sayısını, $n$ sembolü kriter sayısını, $a$ sembolü ilgili kriterler için alternatiflerin aldığı değerleri ifade etmektedir.

Adım 1 - Karar matrisi oluşturulur.

$$
f_{i j}=\left[\begin{array}{cccc}
a_{11} & a_{12} & \ldots & a_{1 \mathrm{n}} \\
a_{21} & a_{22} & \ldots & a_{2 \mathrm{n}} \\
a_{31} & a_{32} & \ldots & a_{3 \mathrm{n}} \\
\ldots & \ldots & \ldots & \ldots \\
a_{\mathrm{m} 1} & a_{\mathrm{m} 2} & \ldots & a_{m n}
\end{array}\right]
$$

Adım 2 - Alternatiflerin değerlendirildiği kriterler içindeki, ideal $\left(f_{i}^{*}\right)$ ve negatif ideal $\left(f_{i}^{-}\right)$değerler kümesi oluşturulur. $i=1,2, \ldots, n$ İdeal $\left(f_{i}^{*}\right)$ çözüm seti her bir kriter için, ilgili kriterin minimum olması isteniyorsa kriter değerlerinin en küçüğü, ilgili kriterin maksimum olması isteniyorsa kriter değerlerinin en büyüğü seçilerek oluşturulur.

$$
f_{i}^{*}=\left\{\left(\max _{i} f_{i j} \mid j \in J\right),\left(\min _{i} \quad f_{i j} \mid j \in J^{\prime}\right)\right\} \Rightarrow f_{i}^{*}=\left\{x_{1}, x_{2}, \ldots, x_{n}\right\}
$$

Negatif ideal $\left(f_{i}^{-}\right)$çözüm seti her bir kriter için, ilgili kriterin minimum olması isteniyorsa kriter değerlerinin en büyüğü, ilgili kriterin maksimum olması isteniyorsa kriter değerlerinin en küçüğü seçilerek oluşturulur.

$$
f_{i}^{-}=\left\{\left(\min _{i} \quad f_{i j} \mid j \in J\right) \quad,\left(\max _{i} \quad f_{i j} \mid j \in J^{\prime}\right)\right\} \Rightarrow f_{i}^{-}=\left\{x_{1}, x_{2}, \ldots, x_{n}\right\}
$$

Adım 3 - $S_{j}$ ve $R_{j}$ değerleri hesaplanır. Bu hesaplamada $w_{i}$ ilgili kriterlerin ağırlıklarını ifade etmektedir. $j=1,2, \ldots, m$

$$
\begin{aligned}
& S_{j}=\sum_{i=1}^{n} w_{i} \cdot \frac{\left(f_{i}^{*}-f_{i j}\right)}{\left(f_{i}^{*}-f_{i}^{-}\right)} \\
& R_{j}=\max _{i}\left[w_{i} \cdot \frac{\left(f_{i}^{*}-f_{i j}\right)}{\left(f_{i}^{*}-f_{i}^{-}\right)}\right]
\end{aligned}
$$

Adım 4 - $Q_{j}$ değerleri hesaplanır. Bu hesaplamadaki $v$ değeri stratejiye bağlı olarak belirlenmiş olan katsayıdır. $0 \leq v \leq 1$ aralığında değer alır. Maksimum grup faydası isteniyorsa 0,5 kabul edilebilir. $j=1,2, \ldots, m$

$$
\begin{aligned}
& Q_{j}=v\left(S_{j}-S^{*}\right) /\left(S^{-}-S^{*}\right)+(1-v)\left(R_{j}-R^{*}\right) /\left(R^{-}-R^{*}\right) \\
& S^{*}=\min _{j} S_{j}, \quad S^{-}=\max _{j} S_{j} \quad, R^{*}=\min _{j} R_{j} \quad, R^{-}=\max _{j} R_{j}
\end{aligned}
$$

Adım 5 - Alternatifler sıralanır. Bu adımda alternatifler $S_{j}, R_{j}$ ve $Q_{j}$ değerlerine göre küçükten büyüğe sıralanır. Sonuç olarak üç adet sıralı liste elde edilir.

Adım 6 - Aşağıdaki iki koşulun sağlanması şartıyla $Q_{\min }$ değerine sahip $d$ alternatifi en iyi veya en uygun olarak nitelendirilebilir.

Birinci Koşul: Kabul edilebilir avantaj koşuludur. $J$ alternatif sayısını göstermek kaydıyla $D Q=1 /(J-1)$ olmak üzere, $a^{\prime \prime}$ sıralanmış listeye göre ikinci alternatifi, $a^{\prime}$ sıralanmış listeye göre birinci alternatifi ifade etmek şartıyla aşağıdaki koşul sağlanmalıdır.

$$
Q\left(a^{\prime \prime}\right)-Q\left(a^{\prime}\right) \geq D Q
$$

İkinci Koşul: Kabul edilebilir istikrar koşuludur. Bu koşulda $d$ alternatifi S ve/veya R sıralamasına göre birinci sırada yer almalıdır.

Bu iki koşul sağlanamıyorsa uzlaşık çözüm kümesi aşağıdaki iki seçenek kullanılarak önerilebilir.

a. Sadece ikinci koşul sağlanamıyorsa $a^{\prime}$ ve $a^{\prime \prime}$,

b. Birinci koşul sağlanamıyorsa $a^{\prime}, a^{\prime \prime}, \ldots, a^{(M)}$. Buradaki $a^{(M)}$ ifadesinde kullanılan $M_{\text {max }}$ değeri belirlenirken $Q\left(a^{(M)}\right)-$ $Q\left(a^{\prime}\right)<D Q$ ilişkisinden yararlanılır.

Sonuç olarak en iyi alternatif, $Q$ değerlerine göre sıralanmış listedeki en küçük değere sahip olan alternatiftir. Tüm sıralama listelerinin oluşturulmasındaki amaç koşul sağlanmadığında uzlaşık sonuç üretebilmek ve strateji oluşturulmasında fayda sağlayabilmek içindir.

Uygulama öncesinde araştırmanın amacı ve yöntemi hakkında aktarılan bilgiler sayesinde, yöneticilerin ve anket katılımcılarının konuya hakimiyetlerinin yeterli olduğu ve değerlendirme sürecinde samimi cevaplar verdikleri varsayılmıştır. Bu çalışma, 2020 yılında Türkiye'de faaliyet gösteren bir uçak bakım organizasyonunda yapılmıştır. Yetkinliklerin nasıl belirlendiği ve hangi parametrelerden etkilendiği üzerinde durulmamıştır. Yetkinliklerin belirlenme sürecinde çalışmanın yapıldığı yıl itibariyle geçerli 
olan SHGM talimatlarından faydalanılmıştır. Uygulama, ilgili organizasyonun yöneticileri ve çalışanları ile gerçekleştirilmiştir. Uygulama için gerekli olan veriler bakım organizasyonunun yetkisi kapsamındaki uçak tiplerinden elde edilmiştir.

\section{BULGULAR}

Bu bölüm iki alt bölümden oluşmaktadır. Birinci alt bölümde, açıklanmış olan veri toplama yöntemleri kullanılarak elde edilmiş olan veriler bulunmaktadır. İkinci alt bölümde, seçilmiş ÇKKV yöntemleri kullanılarak elde edilmiş bulgular bulunmaktadır. Birebir görüşmeler, anket uygulaması ve bilgisayar veri tabanı olarak özetleyebileceğimiz üç farklı veri kaynağı kullanılmıştır. Birebir görüşmelerin her turunda elde edilen nihai sonuçlar bir sonraki görüşmeye başlamadan önce karar vericilerle paylaşılmıştır. Bu sayede, karar vericilerin nihai sonuçlar üzerinde mutabık kalması sağlanmıştır.

Sektör deneyimi olan departman yöneticilerinden oluşan dört adet uzman karar vericiyle operasyonel kriterlerin karşılaştırılması amacıyla birebir görüşme yapılmıştır. Görüşmeler esnasında elde edilen karşılaştırma verileri Excel uygulaması aracılığıyla toplanmıştır. Karar vericilerden toplanan verilerin grup kararına dönüştürülmesi amacıyla, ilk olarak her bir operasyonel kriterin geometrik ortalaması hesaplanmış ve sonrasında normalizasyon işlemi yapılmıştır. Normalizasyon işlemi neticesinde elde edilen nihai kriter ağırlıkları Şekil 5'deki grafikte gösterilmiştir.

\section{Şekil 5: Operasyonel Kriterlerin Nihai Ağırlıkları}

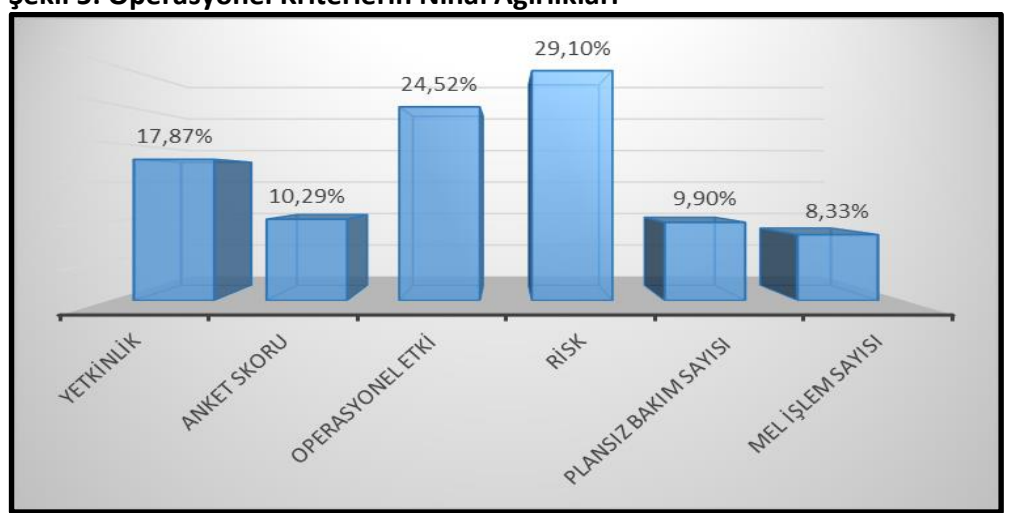

Alternatiflerin belirlenmesi sürecinde altı adımdan oluşan ABC analizi yapılmıştır. İlk olarak, araştırmanın yapıldığı organizasyonda son beş yıl içinde yapılan plansız bakım işlerinin listesi oluşturulmuştur. Oluşturulan listedeki bakım işleri uçak sistemleri bazında kategorize edilmiştir. Sonrasında sistemlerin bakım işi sayısına göre kümülatif dağılımları yüzde olarak hesaplanmış ve $A$, B ve $C$ olmak üzere üç kategoriye ayrılmıştır. A ve B kategorileri araştırma kapsamında alternatif sistemler olarak seçilmiştir. Alternatif sistemler listesinde çalışma alanı ve gerekli yetkinliklerin aynı olması sebebiyle uçak motor sistemleri tek bir grup altında toplanmıştır. Organizasyon bünyesinde yapısal ve kabin içi bakımlarından sorumlu ayrı bakım ekiplerinin bulunması sebebiyle bu sistemler listeye dahil edilmemiştir ve bu sebeple anket uygulaması yapısal ve kabin içi bakım ekiplerine uygulanmamıştır. Alternatiflerin belirlenmesi için oluşturulmuş model Şekil $6^{\prime}$ da gösterilmiştir.

\section{Şekil 6: Alternatiflerin Belirlenmesi}

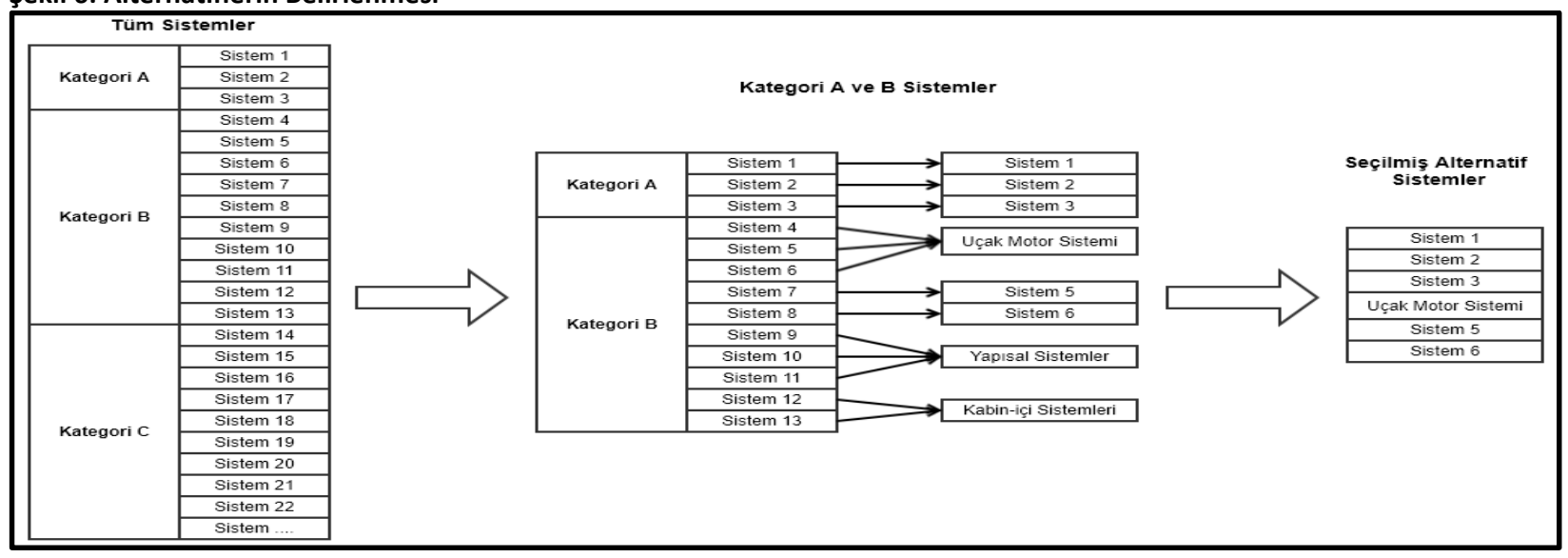

Bu modele göre seçilmiş alternatif uçak sistemlerinin nihai listesi Tablo 4'de gösterilmiştir. 
Tablo 4: Alternatif Uçak Sistemlerinin Nihai Listesi

\begin{tabular}{|c|c|c|c|c|c|}
\hline Kategori & Uçak Sistemi & Plansız Bakım Sayısı & Oran & Kümülatif Oran & Bilgi \\
\hline \multirow{6}{*}{ A } & 33 & 21157 & $22,56 \%$ & $50,89 \%$ & Seçildi. \\
\hline & 32 & 6203 & $6,61 \%$ & $57,50 \%$ & Seçildi. \\
\hline & 35 & 4691 & $5,00 \%$ & $62,50 \%$ & Seçildi. \\
\hline & 34 & 3332 & $3,55 \%$ & $71,03 \%$ & Seçildi. \\
\hline & 21 & 2871 & $3,06 \%$ & $74,09 \%$ & Seçildi. \\
\hline & 23 & 2225 & $2,37 \%$ & $79,00 \%$ & Seçildi. \\
\hline \multirow{13}{*}{ B } & 31 & 1921 & $2,05 \%$ & $81,05 \%$ & Seçildi. \\
\hline & 27 & 1582 & $1,69 \%$ & $82,74 \%$ & Seçildi. \\
\hline & 71 & 1377 & $1,47 \%$ & $84,20 \%$ & Uçak Motor altında birleştirildi. \\
\hline & 38 & 1185 & $1,26 \%$ & $85,47 \%$ & Seçildi. \\
\hline & 30 & 1181 & $1,26 \%$ & $86,73 \%$ & Seçildi. \\
\hline & 28 & 1050 & $1,12 \%$ & $87,85 \%$ & Seçildi. \\
\hline & 36 & 973 & $1,04 \%$ & $88,88 \%$ & Seçildi. \\
\hline & 73 & 935 & $1,00 \%$ & $89,88 \%$ & Uçak Motor altında birleştirildi. \\
\hline & 22 & 920 & $0,98 \%$ & $90,86 \%$ & Seçildi. \\
\hline & 78 & 773 & $0,82 \%$ & $91,69 \%$ & Uçak Motor altında birleştirildi. \\
\hline & 72 & 708 & $0,75 \%$ & $92,44 \%$ & Uçak Motor altında birleştirildi. \\
\hline & 29 & 699 & $0,75 \%$ & $93,19 \%$ & Seçildi. \\
\hline & 80 & 680 & $0,73 \%$ & $93,91 \%$ & Uçak Motor altında birleştirildi. \\
\hline
\end{tabular}

Araştırmanın yapıldığı organizasyonda çalışan, uçak bakım lisansı ile en az iki yıl tecrübeye sahip ve yöneticilik veya ekip liderliğine benzer sorumluluğu olmayan uçak bakım personelinin tamamına birebir görüşme aracılığıyla anket uygulanmıştır. Uygulama öncesinde katılımcılara araştırma hakkında bilgi verilmiştir. Verecekleri yanıtların onları ödüllendirmek veya cezalandırmak için kullanılmayacağı özellikle belirtilmiştir. Yanıtlarında samimi olmaları ve kendilerini rahat hissetmeleri için kişisel bilgileri anket ile toplanmamıştır.

Anket sonuçları Şekil 7'de gösterilmiştir. Sonuçlar incelendiğinde genel mesleki yetkinlik sorularını oluşturan ilk iki sorudan oldukça yüksek puan elde edildiği görülmüştür. Bu sonuç genel mesleki yetkinlik açısından personelin istenen düzeyde olduğunu göstermektedir. Sistem bazında anket sonuçları incelendiğinde, uçak bakım personelinin kendisini en az yetkin hissettiği uçak sisteminin otomatik uçuş olduğu görülmüştür. Buna rağmen otomatik uçuş için elde edilen ortalama puanın 4,60 olması en düşük olan sistem için bile yetkinlik seviyesinin oldukça iyi olduğunu göstermektedir.

\section{Şekil 7: Alternatif Uçak Sistemleri Bazında Anket Puanı}

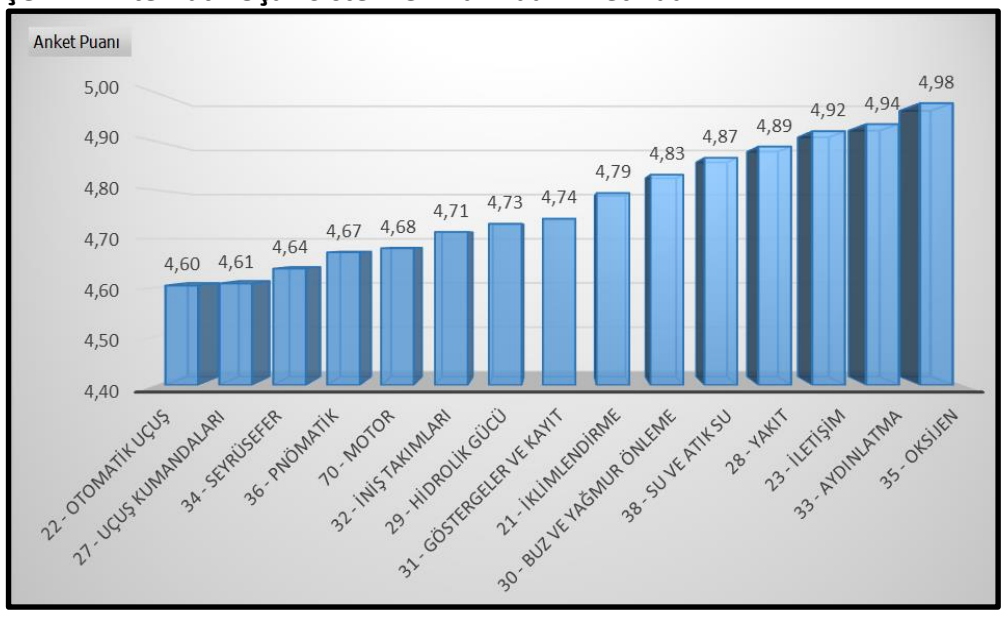

Sektör deneyimi olan departman yöneticilerinden oluşan dört adet uzman karar vericiyle, yetkinliğin alternatifler üzerindeki etkisini belirlemek amacıyla birebir görüşme yapılmıştır. Görüşmeler esnasında elde edilen karşılaştırma verileri Excel uygulaması aracılığıyla toplanmıştır. Karar vericilerden toplanan verilerin grup kararına dönüştürülmesi amacıyla, ilk olarak her bir alternatifin 
geometrik ortalaması hesaplanmış ve sonrasında normalizasyon işlemi yapılmıştır. Normalizasyon işlemi neticesinde elde edilen nihai alternatif ağılıkları Şekil 8'deki grafikte gösterilmiştir.

Şekil 8: Yetkinlik Kriterinin Nihai Ağırlıkları

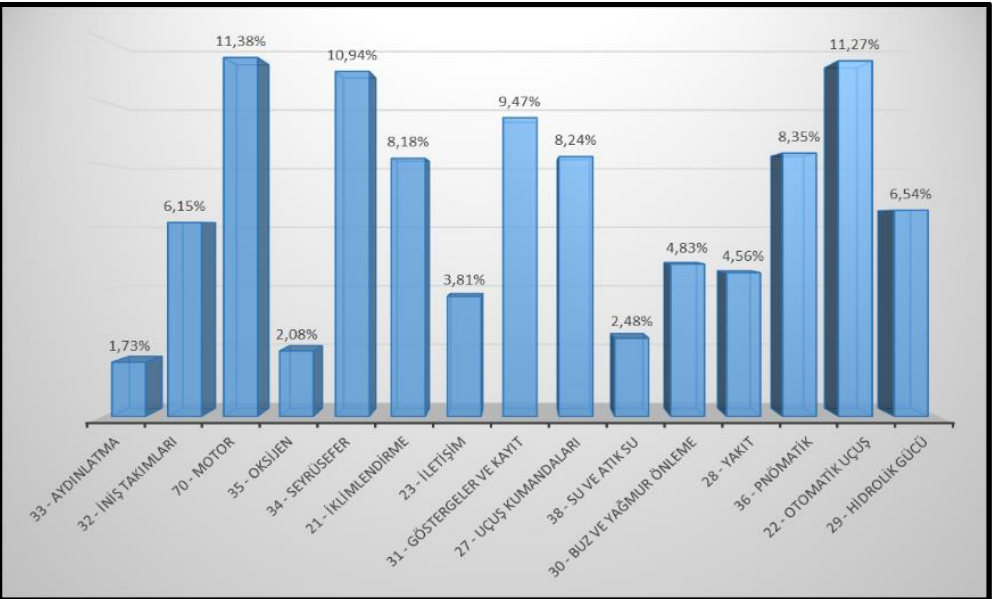

Sektör deneyimi olan departman yöneticilerinden oluşan dört adet uzman karar vericiyle, alternatiflerin operasyonel etkisini belirlemek amacıyla birebir görüşme yapılmıştır. Görüşmeler esnasında elde edilen karşılaştırma verileri Excel uygulaması aracılığıyla toplanmıştır. Karar vericilerden toplanan verilerin grup kararına dönüştürülmesi amacıyla, ilk olarak her bir alternatifin geometrik ortalaması hesaplanmış ve sonrasında normalizasyon işlemi yapılmıştır. Normalizasyon işlemi neticesinde elde edilen nihai alternatif ağırlıkları Şekil 9'daki grafikte gösterilmiştir.

\section{Şekil 9: Operasyonel Etki Kriterinin Nihai Ağırlıkları}

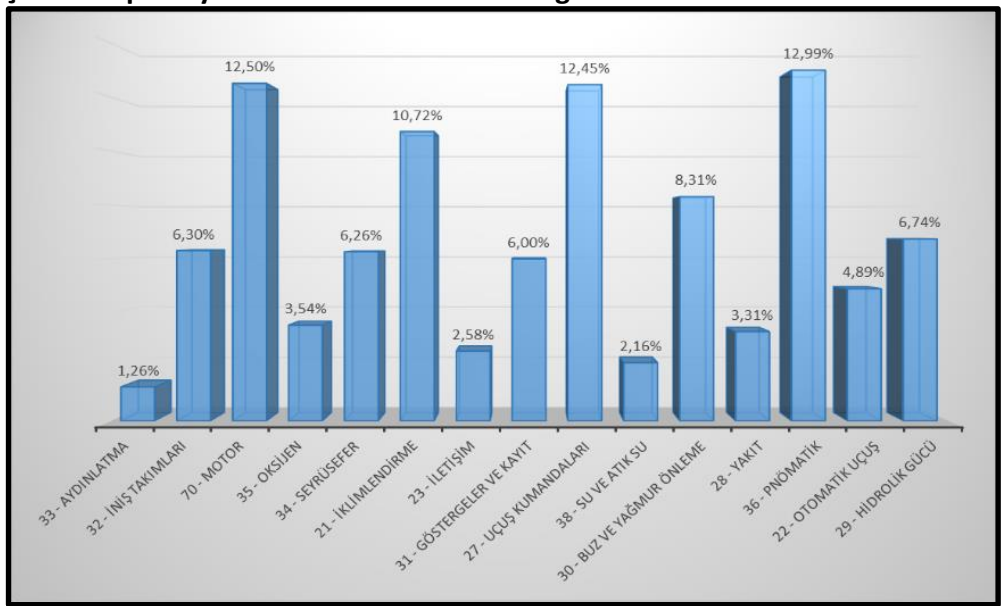

Sektör deneyimi olan teknik departman yöneticilerinden oluşan dört adet uzman karar vericiyle, alternatif uçak sistemlerinin riskini belirleyebilmek amacıyla birebir görüşme yapılmıştır. Görüşmelerde her bir alternatif uçak sisteminin risk analizi yapılmıştır. Karar vericilerden toplanan verilerin grup kararına dönüştürülmesi amacıyla, her bir alternatifin geometrik ortalaması hesaplanmıştır. Hesaplama işlemi neticesinde alternatiflere ait elde edilen nihai risk değerleri Şekil 10'daki grafikte gösterilmiştir. 


\section{Şekil 10: Alternatiflerin nihai risk değerleri}

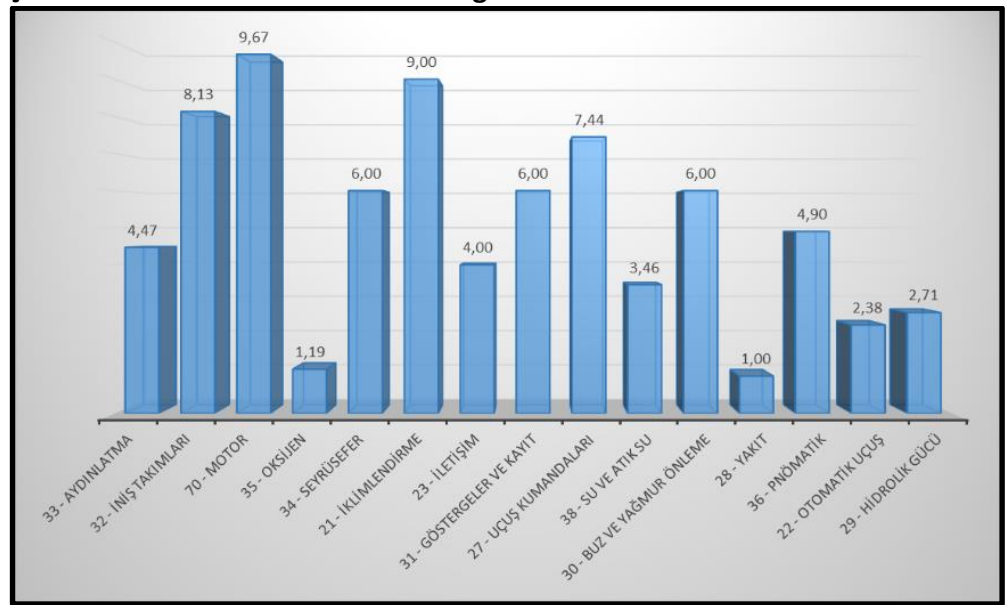

Araştırmanın yapıldığı uçak bakım organizasyonunda son beş yılda gerçekleştirilmiş plansız bakım sayıları bilgisayar veri tabanı aracılığıyla temin edilmiştir. Elde edilen sayılarla Şekil 11'deki grafik oluşturulmuştur. Grafik incelendiğinde, 33 - Aydınlatma sisteminde gerçekleştirilmiş olan plansız bakım sayısının diğerlerine oranla oldukça fazla olduğu görülmüştür. Bu kadar fazla olmasındaki temel sebep incelenmiş ve uçakta aydınlatma amacıyla kullanılan lamba sayısının fazla olduğu görülmüştür.

\section{Şekil 11: Alternatiflere ait plansız bakım sayıları}

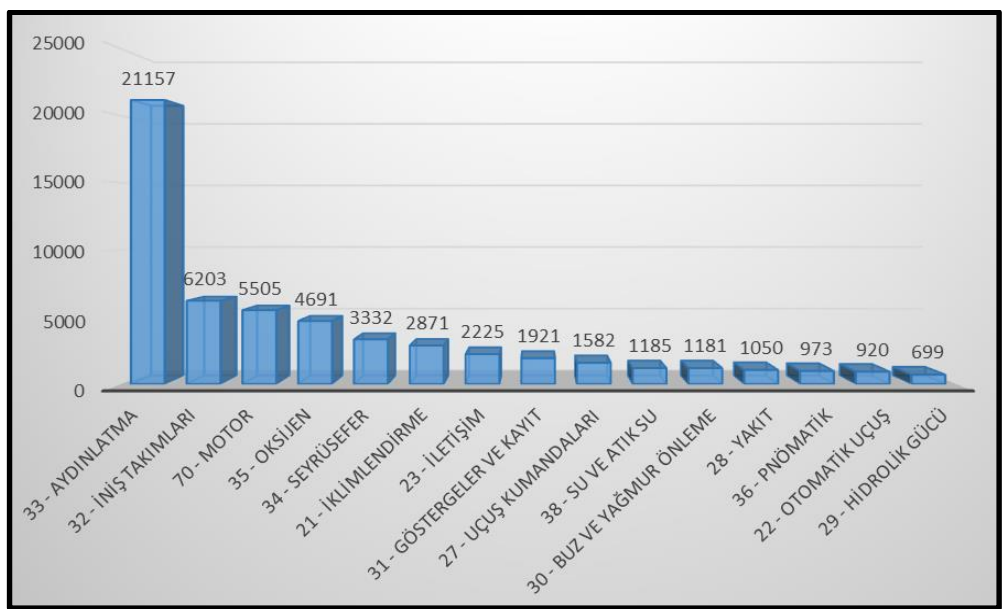

Araştırmanın yapıldığı uçak bakım organizasyonunda son beş yılda gerçekleştirilmiş MEL işlem sayıları bilgisayar veri tabanı aracılığıyla temin edilmiştir. Elde edilen sayılarla Tablo 5 oluşturulmuştur. Her bir alternatife ait kategori $A, B$ ve $C$ bazında $\mathrm{MEL}$ işlem sayıları Tablo 5'den görülebilir. Kategori D MEL işlem sayısı son derece az olduğu için araştırma kapsamında dikkate alınmamıştır. 33 - Aydınlatma sistemine ait Kategori C MEL işlem sayısının diğer alternatif uçak sistemlerine göre oldukça fazla olduğu görülmüştür. Aydınlatma sistemi arızalarının bu kadar fazla olmasındaki temel sebep, gündüz koşullarında aydınlatma kısmen gereksiz olduğu için arızayı çözmek yerine daha uygun bir zamana arıza çözme işleminin ötelenmesi ve uçakta kullanılan ekipman sayısının çok fazla olması söylenebilir.

Tablo 5: Alternatiflere ait MEL işlem sayıları

\begin{tabular}{|l|c|c|c|}
\hline Alternatif uçak sistemi & Kategori A & Kategori B & Kategori C \\
\hline 33 - Aydınlatma & 1 & 41 & 4594 \\
\hline 32 - İniş Takımları & 8 & 5 & 338 \\
\hline 70 - Motor & 60 & 5 & 746 \\
\hline 35 - Oksijen & 31 & 7 & 28 \\
\hline 34 - Seyrüsefer & 154 & 70 & 543 \\
\hline
\end{tabular}




\begin{tabular}{|l|c|c|c|}
\hline 21 - İklimlendirme & 1 & 21 & 641 \\
\hline 23 - İletişim & 57 & 159 & 461 \\
\hline 31 - Göstergeler ve Kayıt & 19 & 4 & 120 \\
\hline 27 - Uçuş Kumandaları & 4 & 2 & 169 \\
\hline 38 - Su ve Atık Su & 2 & 0 & 925 \\
\hline 30 - Buz ve Yağmur Önleme & 2 & 9 & 621 \\
\hline 28 - Yakıt & 0 & 0 & 359 \\
\hline 36 - Pnömatik & 0 & 1 & 619 \\
\hline 22 - Otomatik Uçuş & 60 & 3 & 280 \\
\hline 29 - Hidrolik Gücü & 0 & 0 & 123 \\
\hline
\end{tabular}

Bu bölümde, toplanmış veriler kullanılarak, seçilmiş ÇKKV yöntemlerinin kullanılmasıyla elde edilen bulgular yer almaktadır. İlk olarak TOPSIS, sonrasında da VIKOR yöntemi kullanılarak hesaplamalar yapılmıştır. Hesaplamaların her aşamasında elde edilen sonuçlar tablolar halinde gösterilmiştir.

Adım 1: Toplanmış verilerle oluşturulmuş karar matrisi Tablo 6'da yer almaktadır. Birebir görüşmelerle belirlenmiş olan operasyonel kriterler yatay eksene ve $A B C$ analizi yaparak elde edilmiş alternatif uçak sistemleri dikey eksene yerleştirilmiştir.

Tablo 6: TOPSIS Karar Matrisi

\begin{tabular}{|l|c|c|c|c|c|c|c|c|}
\hline Alternatif Uçak Sistemi & Yetkinlik & $\begin{array}{c}\text { Anket } \\
\text { Skoru }\end{array}$ & $\begin{array}{c}\text { Operasyonel } \\
\text { Etki }\end{array}$ & Risk & $\begin{array}{c}\text { Plansız Bakım } \\
\text { Sayısı }\end{array}$ & $\begin{array}{c}\text { MEL A } \\
\text { Kategori }\end{array}$ & $\begin{array}{c}\text { MEL B } \\
\text { Kategori }\end{array}$ & $\begin{array}{c}\text { MEL C } \\
\text { Kategori }\end{array}$ \\
\hline 33 - Aydınlatma & 0,0173 & 4,9351 & 0,0126 & 4,4721 & 21157 & 1 & 41 & 4594 \\
\hline 32 - Iniş Takımları & 0,0615 & 4,7141 & 0,0630 & 8,1324 & 6203 & 8 & 5 & 338 \\
\hline 70 - Motor & 0,1138 & 4,6806 & 0,1250 & 9,6711 & 5505 & 60 & 5 & 746 \\
\hline 35 - Oksijen & 0,0208 & 4,9780 & 0,0354 & 1,1892 & 4691 & 31 & 7 & 28 \\
\hline 34 - Seyrüsefer & 0,1094 & 4,6387 & 0,0626 & 6,0000 & 3332 & 154 & 70 & 543 \\
\hline 21 - Iklimlendirme & 0,0818 & 4,7937 & 0,1072 & 9,0000 & 2871 & 1 & 21 & 641 \\
\hline 23 - Iletişim & 0,0381 & 4,9204 & 0,0258 & 4,0000 & 2225 & 57 & 159 & 461 \\
\hline 31 - Göstergeler ve Kayıt & 0,0947 & 4,7414 & 0,0600 & 6,0000 & 1921 & 19 & 4 & 120 \\
\hline 27 - Uçuş Kumandaları & 0,0824 & 4,6084 & 0,1245 & 7,4448 & 1582 & 4 & 2 & 169 \\
\hline 38 - Su ve Atık Su & 0,0248 & 4,8660 & 0,0216 & 3,4641 & 1185 & 2 & 0 & 925 \\
\hline 30 - Buz ve Yağmur Önleme & 0,0483 & 4,8314 & 0,0831 & 6,0000 & 1181 & 2 & 9 & 621 \\
\hline 28 - Yakıt & 0,0456 & 4,8890 & 0,0331 & 1,0000 & 1050 & 0 & 0 & 359 \\
\hline 36 - Pnömatik & 0,0835 & 4,6723 & 0,1299 & 4,8990 & 973 & 0 & 1 & 619 \\
\hline 22 - Otomatik Uçuş & 0,1127 & 4,6042 & 0,0489 & 2,3784 & 920 & 60 & 3 & 280 \\
\hline 29 - Hidrolik Gücü & 0,0654 & 4,7309 & 0,0674 & 2,7108 & 699 & 0 & 0 & 123 \\
\hline
\end{tabular}

Adım 2: Tablo 7'de görülen karar matrisi üzerinde vektör normalizasyonu yapıldıktan sonra elde edilen yeni değerler Tablo 7'de yer almaktadır. Normalizasyon işlemi için 14 numaralı denklem kullanılmıştır.

Tablo 7: Normalize Edilmiş TOPSIS Karar Matrisi

\begin{tabular}{|l|c|c|c|c|c|c|c|c|}
\hline Alternatif Uçak Sistemi & Yetkinlik & $\begin{array}{c}\text { Anket } \\
\text { Skoru }\end{array}$ & $\begin{array}{c}\text { Operasyonel } \\
\text { Etki }\end{array}$ & Risk & $\begin{array}{c}\text { Plansız Bakım } \\
\text { Sayısı }\end{array}$ & $\begin{array}{c}\text { MEL A } \\
\text { Kategori }\end{array}$ & $\begin{array}{c}\text { MEL B } \\
\text { Kategori }\end{array}$ & $\begin{array}{c}\text { MEL C } \\
\text { Kategori }\end{array}$ \\
\hline 33 - Aydınlatma & 0,060 & 0,267 & 0,042 & 0,202 & 0,882 & 0,005 & 0,227 & 0,927 \\
\hline 32 - Iniş Takımları & 0,214 & 0,255 & 0,212 & 0,367 & 0,259 & 0,042 & 0,028 & 0,068 \\
\hline 70 - Motor & 0,397 & 0,253 & 0,420 & 0,436 & 0,230 & 0,318 & 0,028 & 0,150 \\
\hline 35 - Oksijen & 0,072 & 0,269 & 0,119 & 0,054 & 0,196 & 0,164 & 0,039 & 0,006 \\
\hline 34 - Seyrüsefer & 0,381 & 0,251 & 0,211 & 0,271 & 0,139 & 0,816 & 0,388 & 0,110 \\
\hline 21 - Iklimlendirme & 0,285 & 0,259 & 0,360 & 0,406 & 0,120 & 0,005 & 0,116 & 0,129 \\
\hline 23 - Iletişim & 0,133 & 0,266 & 0,087 & 0,180 & 0,093 & 0,302 & 0,882 & 0,093 \\
\hline 31 - Göstergeler ve Kayıt & 0,330 & 0,256 & 0,202 & 0,271 & 0,080 & 0,101 & 0,022 & 0,024 \\
\hline 27 - Uçuş Kumandaları & 0,287 & 0,249 & 0,419 & 0,336 & 0,066 & 0,021 & 0,011 & 0,034 \\
\hline 38 - Su ve Atık Su & 0,087 & 0,263 & 0,073 & 0,156 & 0,049 & 0,011 & 0,000 & 0,187 \\
\hline 30 - Buz ve Yağmur Önleme & 0,168 & 0,261 & 0,279 & 0,271 & 0,049 & 0,011 & 0,050 & 0,125 \\
\hline
\end{tabular}




\begin{tabular}{|l|l|l|l|l|l|l|l|l|}
\hline 28 - Yakıt & 0,159 & 0,264 & 0,111 & 0,045 & 0,044 & 0,000 & 0,000 & 0,072 \\
\hline 36 - Pnömatik & 0,291 & 0,253 & 0,437 & 0,221 & 0,041 & 0,000 & 0,006 & 0,125 \\
\hline 22 - Otomatik Uçuş & 0,393 & 0,249 & 0,164 & 0,107 & 0,038 & 0,318 & 0,017 & 0,056 \\
\hline 29 - Hidrolik Gücü & 0,228 & 0,256 & 0,226 & 0,122 & 0,029 & 0,000 & 0,000 & 0,025 \\
\hline
\end{tabular}

Adım 3: Tablo 8'de görülen normalize edilmiş karar matrisi operasyonel kriterlere ait AHP ile hesaplanmış ağırlık değerleriyle çarpılarak ağırlıklandııılmış normalize edilmiş matris oluşturulmuştur. Bu noktada MEL iş̧lem Sayısı kriteri için belirlenmiş olan ağılık değeri her bir MEL kategorisine kategoriler için belirlenmiş olan gün sayısıyla ters orantılı olarak dağıtılmıştır. Ağırlık değerleri MEL Kategori A (1 gün) için 0.0581, MEL Kategori B (3 gün) için 0.0194 ve MEL Kategori C (10 gün) için 0.0058 olarak alınmıştır. Çarpımlar neticesinde elde edilmiş olan yeni değerler Tablo 8'de yer almaktadır.

Tablo 8: Ağırlıklandırılmış Normalize Edilmiş TOPSıS Karar Matrisi

\begin{tabular}{|l|c|c|c|c|c|c|c|c|}
\hline Alternatif Uçak Sistemi & Yetkinlik & $\begin{array}{c}\text { Anket } \\
\text { Skoru }\end{array}$ & $\begin{array}{c}\text { Operasyonel } \\
\text { Etki }\end{array}$ & Risk & $\begin{array}{c}\text { Plansız Bakım } \\
\text { Sayısı }\end{array}$ & $\begin{array}{c}\text { MEL A } \\
\text { Kategori }\end{array}$ & $\begin{array}{c}\text { MEL B } \\
\text { Kategori }\end{array}$ & $\begin{array}{c}\text { MEL C } \\
\text { Kategori }\end{array}$ \\
\hline 33 - Aydınlatma & 0,011 & 0,027 & 0,010 & 0,059 & 0,087 & 0,000 & 0,004 & 0,005 \\
\hline 32 - Innş̧ Takımları & 0,038 & 0,026 & 0,052 & 0,107 & 0,026 & 0,002 & 0,001 & 0,000 \\
\hline 70 - Motor & 0,071 & 0,026 & 0,103 & 0,127 & 0,023 & 0,018 & 0,001 & 0,001 \\
\hline 35 - Oksijen & 0,013 & 0,028 & 0,029 & 0,016 & 0,019 & 0,010 & 0,001 & 0,000 \\
\hline 34 - Seyrüsefer & 0,068 & 0,026 & 0,052 & 0,079 & 0,014 & 0,047 & 0,008 & 0,001 \\
\hline 21 - İklimlendirme & 0,051 & 0,027 & 0,088 & 0,118 & 0,012 & 0,000 & 0,002 & 0,001 \\
\hline 23 - Iletişim & 0,024 & 0,027 & 0,021 & 0,052 & 0,009 & 0,018 & 0,017 & 0,001 \\
\hline 31 - Göstergeler ve Kayıt & 0,059 & 0,026 & 0,049 & 0,079 & 0,008 & 0,006 & 0,000 & 0,000 \\
\hline 27 - Uçuş Kumandaları & 0,051 & 0,026 & 0,103 & 0,098 & 0,007 & 0,001 & 0,000 & 0,000 \\
\hline 38 - Su ve Atık Su & 0,015 & 0,027 & 0,018 & 0,045 & 0,005 & 0,001 & 0,000 & 0,001 \\
\hline 30 - Buz ve Yağmur Önleme & 0,030 & 0,027 & 0,068 & 0,079 & 0,005 & 0,001 & 0,001 & 0,001 \\
\hline 28 - Yakıt & 0,028 & 0,027 & 0,027 & 0,013 & 0,004 & 0,000 & 0,000 & 0,000 \\
\hline 36 - Pnömatik & 0,052 & 0,026 & 0,107 & 0,064 & 0,004 & 0,000 & 0,000 & 0,001 \\
\hline 22 - Otomatik Uçuş & 0,070 & 0,026 & 0,040 & 0,031 & 0,004 & 0,018 & 0,000 & 0,000 \\
\hline 29 - Hidrolik Gücü & 0,041 & 0,026 & 0,056 & 0,036 & 0,003 & 0,000 & 0,000 & 0,000 \\
\hline
\end{tabular}

Adım 4: İdeal $\left(A^{*}\right)$ ve negatif ideal $\left(A^{-}\right)$çözüm setlerinin oluşturulması amacıyla her bir kriter için aranan değer özelliği Tablo 4.6'daki gibi belirlenmiştir. Tablo 8'den yararlanarak oluşturulmuş olan çözüm setleri Tablo 9'da yer almaktadır.

Tablo 9: Kriter Özellikleri

\begin{tabular}{|l|c|l|}
\hline Kriter & Aranan değer & Açılama \\
\hline Yetkinlik & Maksimum & $\begin{array}{l}\text { En kompleks uçak sisteminin saptanabilmesi amacıyla, bu kriter için en yüksek yetkinlik } \\
\text { gerektiren uçak sistemi aranıyor. }\end{array}$ \\
\hline Anket Skoru & Minimum & $\begin{array}{l}\text { Personel yetkinliğinin en düşük olduğu uçak sistemini saptamak amaçyla anket skoru } \\
\text { kriterinin en düşük olduğu uçak sistemi aranıyor. }\end{array}$ \\
\hline Operasyonel Etki & Maksimum & $\begin{array}{l}\text { Operasyonu en çok etkileme potansiyeline sahip olan uçak sistemini saptamak amacıyla } \\
\text { operasyonel etki kriterinin en yüksek olduğu uçak sistemi aranıyor. }\end{array}$ \\
\hline Risk & Maksimum & $\begin{array}{l}\text { En yüksek riske sahip olan uçak sistemini saptamak amacıyla risk kriterinin en yüksek } \\
\text { olduğu uçak sistemi aranıyor. }\end{array}$ \\
\hline $\begin{array}{l}\text { Plansız Bakım } \\
\text { Sayısı }\end{array}$ & Maksimum & $\begin{array}{l}\text { En fazla arıza ile karşılaşılan uçak sistemini saptamak amacıyla plansız bakım sayısı } \\
\text { kriterinin en yüksek olduğu uçak sistemi aranıyor. }\end{array}$ \\
\hline MEL A Kategori & Maksimum & $\begin{array}{l}\text { Karşılaşılan arızalardan anlık olarak en çok çözülemeyen arızaya sahip uçak sistemini } \\
\text { saptamak amacıyla MEL A Kategori kriterinin en yüksek olduğu uçak sistemi aranıyor. }\end{array}$ \\
\hline MEL B Kategori & Maksimum & $\begin{array}{l}\text { Karşılaşılan arıalardan anlık olarak en çok çözülemeyen arızaya sahip uçak sistemini } \\
\text { saptamak amacıyla MEL B Kategori kriterinin en yüksek olduğu uçak sistemi aranıyor. }\end{array}$ \\
\hline MEL C Kategori & Maksimum & $\begin{array}{l}\text { Karşılaşılan arızalardan anlık olarak en çok çözülemeyen arızaya sahip uçak sistemini } \\
\text { saptamak amacıly MEL C Kategori kriterinin en yüksek olduğu uçak sistemi aranıyor. }\end{array}$ \\
\hline
\end{tabular}


Tablo 10: TOPSIS İçin İdeal ve Negatif İdeal Çözüm Setleri

\begin{tabular}{|l|c|c|c|c|c|c|c|c|}
\hline & Yetkinlik & $\begin{array}{c}\text { Anket } \\
\text { Skoru }\end{array}$ & $\begin{array}{c}\text { Operasyonel } \\
\text { Etki }\end{array}$ & Risk & $\begin{array}{c}\text { Plansız } \\
\text { Bakım Sayısı }\end{array}$ & $\begin{array}{c}\text { MEL A } \\
\text { Kategori }\end{array}$ & $\begin{array}{c}\text { MEL B } \\
\text { Kategori }\end{array}$ & $\begin{array}{c}\text { MEL C } \\
\text { Kategori }\end{array}$ \\
\hline$F^{*}$ (en iyi) & 0,071 & 0,026 & 0,107 & 0,127 & 0,087 & 0,047 & 0,017 & 0,005 \\
\hline$F^{\prime}$ (en kötü) & 0,011 & 0,028 & 0,010 & 0,013 & 0,003 & 0,000 & 0,000 & 0,000 \\
\hline
\end{tabular}

Adım 5: Bu adımda 3.19 ve 3.20 numaralı denklemler kullanılarak ideal ve negatif ideal uzaklık değerleri hesaplanmıştır. Hesaplanmış ideal $\left(A^{*}\right)$ ve negatif ideal $\left(A^{-}\right)$noktalara olan uzaklık değerleri Tablo $10^{\prime}$ da yer almaktadır.

Tablo 11: TOPSIS için ideal ve negatif ideal noktalara olan uzaklık değerleri

\begin{tabular}{|l|c|c|}
\hline Alternatif Uçak Sistemi & $\begin{array}{c}\text { İeal Uzaklık } \\
A^{*}\end{array}$ & $\begin{array}{c}\text { Negatif Ideal Uzaklık } \\
A^{-}\end{array}$ \\
\hline 33 - Aydınlatma & 0,1415 & 0,0962 \\
\hline 32 - İniş Takımları & 0,1031 & 0,1085 \\
\hline 70 - Motor & 0,0729 & 0,1609 \\
\hline 35 - Oksijen & 0,1678 & 0,0270 \\
\hline 34 - Seyrüsefer & 0,1045 & 0,1083 \\
\hline 21 - İklimlendirme & 0,0948 & 0,1372 \\
\hline 23 - İletişim & 0,1488 & 0,0498 \\
\hline 31 - Göstergeler ve Kayıt & 0,1188 & 0,0907 \\
\hline 27 - Uçuş Kumandaları & 0,1011 & 0,1317 \\
\hline 38 - Su ve Atık Su & 0,1643 & 0,0336 \\
\hline 30 - Buz ve Yağmur Önleme & 0,1214 & 0,0898 \\
\hline 28 - Yakıt & 0,1749 & 0,0245 \\
\hline 36 - Pnömatik & 0,1174 & 0,1170 \\
\hline 22 - Otomatik Uçuş & 0,1474 & 0,0715 \\
\hline 29 - Hidrolik Gücü & 0,1470 & 0,0587 \\
\hline
\end{tabular}

Adım 6: Bu adımda 3.21 numaralı denklem kullanılarak ideal çözüme göreli yakınlık değerleri hesaplanmış ve hesaplanan değerlere göre alternatifler sıralanmıştır. Tablo 11'den yararlanarak hesaplanmış olan ideal çözüme göreli yakınlık değerleri ve nihai sıralama Tablo 12 'de yer almaktadır.

Tablo 12: TOPSıS İçin Nihai Sıralama

\begin{tabular}{|l|c|c|}
\hline Alternatif Uçak Sistemi & ideal Çözüme Göreli Yakınlık Değeri & Nihai Sıralama \\
\hline 33 - Aydınlatma & 0,4047 & 9 \\
\hline 32 - İniş Takımları & 0,5127 & 4 \\
\hline 70 - Motor & 0,6881 & 1 \\
\hline 35 - Oksijen & 0,1386 & 14 \\
\hline 34 - Seyrüsefer & 0,5089 & 5 \\
\hline 21 - İlimlendirme & 0,5914 & 2 \\
\hline 23 - Iletişim & 0,2507 & 12 \\
\hline 31 - Göstergeler ve Kayıt & 0,4328 & 7 \\
\hline 27 - Uçuş Kumandaları & 0,5656 & 3 \\
\hline 38 - Su ve Atık Su & 0,1698 & 13 \\
\hline
\end{tabular}




\begin{tabular}{|l|c|c|}
\hline 30 - Buz ve Yağmur Önleme & 0,4252 & 8 \\
\hline 28 - Yakıt & 0,1228 & 15 \\
\hline 36 - Pnömatik & 0,4991 & 6 \\
\hline 22 - Otomatik Uçuş & 0,3265 & 10 \\
\hline 29 - Hidrolik Gücü & 0,2853 & 11 \\
\hline
\end{tabular}

Bu adımın tamamlanmasıyla TOPSIS için nihai sıralama elde edilmiş olur. Bir sonraki bölümde VIKOR için nihai sıralama elde edilecek ve sonrasında her iki yöntem ile elde edilmiş olan sıralamalar karşılaştırılacaktır.

Adım 1: Toplanmış verilerle oluşturulmuş karar matrisi Tablo 13'de yer almaktadır. Birebir görüşmelerle belirlenmiş olan operasyonel kriterler yatay eksene ve $A B C$ analizi yaparak elde edilmiş alternatif uçak sistemleri dikey eksene yerleştirilmiştir.

Tablo 13: VIKOR Karar Matrisi

\begin{tabular}{|c|c|c|c|c|c|c|c|c|}
\hline Alternatif Uçak Sistemi & Yetkinlik & $\begin{array}{l}\text { Anket } \\
\text { Skoru }\end{array}$ & $\begin{array}{c}\text { Operasyonel } \\
\text { Etki }\end{array}$ & Risk & $\begin{array}{c}\text { Plansız } \\
\text { Bakım Sayısı }\end{array}$ & $\begin{array}{c}\text { MEL A } \\
\text { Kategori }\end{array}$ & $\begin{array}{c}\text { MEL B } \\
\text { Kategori }\end{array}$ & $\begin{array}{c}\text { MEL C } \\
\text { Kategori }\end{array}$ \\
\hline 33 - Aydınlatma & 0,0173 & 4,9351 & 0,0126 & 4,4721 & 21157 & 1 & 41 & 4594 \\
\hline 32 - İniş Takımları & 0,0615 & 4,7141 & 0,0630 & 8,1324 & 6203 & 8 & 5 & 338 \\
\hline 70 - Motor & 0,1138 & 4,6806 & 0,1250 & 9,6711 & 5505 & 60 & 5 & 746 \\
\hline 35 - Oksijen & 0,0208 & 4,9780 & 0,0354 & 1,1892 & 4691 & 31 & 7 & 28 \\
\hline 34 - Seyrüsefer & 0,1094 & 4,6387 & 0,0626 & 6,0000 & 3332 & 154 & 70 & 543 \\
\hline 21 - İklimlendirme & 0,0818 & 4,7937 & 0,1072 & 9,0000 & 2871 & 1 & 21 & 641 \\
\hline 23 - Iletişim & 0,0381 & 4,9204 & 0,0258 & 4,0000 & 2225 & 57 & 159 & 461 \\
\hline 31 - Göstergeler ve Kayıt & 0,0947 & 4,7414 & 0,0600 & 6,0000 & 1921 & 19 & 4 & 120 \\
\hline 27 - Uçuş Kumandaları & 0,0824 & 4,6084 & 0,1245 & 7,4448 & 1582 & 4 & 2 & 169 \\
\hline 38 - Su ve Atık Su & 0,0248 & 4,8660 & 0,0216 & 3,4641 & 1185 & 2 & 0 & 925 \\
\hline 30 - Buz ve Yağmur Önleme & 0,0483 & 4,8314 & 0,0831 & 6,0000 & 1181 & 2 & 9 & 621 \\
\hline 28 - Yakıt & 0,0456 & 4,8890 & 0,0331 & 1,0000 & 1050 & 0 & 0 & 359 \\
\hline 36 - Pnömatik & 0,0835 & 4,6723 & 0,1299 & 4,8990 & 973 & 0 & 1 & 619 \\
\hline 22 - Otomatik Uçuş & 0,1127 & 4,6042 & 0,0489 & 2,3784 & 920 & 60 & 3 & 280 \\
\hline 29 - Hidrolik Gücü & 0,0654 & 4,7309 & 0,0674 & 2,7108 & 699 & 0 & 0 & 123 \\
\hline
\end{tabular}

Adım 2: Alternatiflerin değerlendirildiği kriterler içindeki, ideal $\left(f_{i}^{*}\right)$ ve negatif ideal $\left(f_{i}^{-}\right)$değerler kümesi Tablo $14^{\prime}$ de görüldüğü gibi oluşturulmuştur. Bu tablo oluşturulurken TOPSIS yönteminde olduğu gibi Tablo 14'deki kriter özelliklerinden faydalanılmıştır. Anket Skoru kriterinden alternatifin alabileceği maksimum değer 5 ve minimum değer 1 olarak belirlenmiştir. Risk kriterinden alternatifin alabileceği maksimum değer 25 ve minimum değer 1 olarak belirlenmiştir.

Tablo 14: VIKOR İçin İdeal ve Negatif İdeal Değerler Kümesi

\begin{tabular}{|l|c|c|c|c|c|c|c|c|}
\hline & Yetkinlik & $\begin{array}{c}\text { Anket } \\
\text { Skoru }\end{array}$ & $\begin{array}{c}\text { Operasyonel } \\
\text { Etki }\end{array}$ & Risk & $\begin{array}{c}\text { Plansız } \\
\text { Bakım Sayısı }\end{array}$ & $\begin{array}{c}\text { MEL A } \\
\text { Kategori }\end{array}$ & $\begin{array}{c}\text { MEL B } \\
\text { Kategori }\end{array}$ & $\begin{array}{c}\text { MEL C } \\
\text { Kategori }\end{array}$ \\
\hline$f_{i}^{*}$ (Ideal) & 0,1138 & 1,0000 & 0,1299 & 25,0000 & 21157 & 154 & 159 & 4594 \\
\hline$f_{i}^{-}$(Negatif ideal) & 0,0173 & 5,0000 & 0,0126 & 1,0000 & 699 & 0 & 0 & 28 \\
\hline
\end{tabular}

Adım 3: Tablo 13 ve 14'deki değerler, 25 ve 26 numaralı denklemler kullanılarak hesaplanmış $S_{j}$ ve $R_{j}$ değerleri Tablo $15^{\prime}$ de yer almaktadır. Bu değerlerin hesaplanmasında açıklanmış olan operasyonel kriterlere ait AHP ile hesaplanmış ağırlık değerleri kullanılmıştır. Bu noktada MEL İşlem Sayısı kriteri için belirlenmiş olan ağılık değeri her bir MEL kategorisine kategoriler için belirlenmiş olan gün sayısıyla ters orantılı olarak dağıtılmıştır. Ağırlık değerleri MEL Kategori A (1 gün) için 0.0581, MEL Kategori B (3 gün) için 0.0194 ve MEL Kategori C (10 gün) için 0.0058 olarak alınmıştır.

Tablo 15: VIKOR İçin Hesaplanmış $S_{j}$ ve $R_{j}$ Değerleri

\begin{tabular}{|l|c|c|}
\hline Alternatif Uçak Sistemi & $\boldsymbol{S}_{\boldsymbol{i}}$ & $\boldsymbol{R}_{\boldsymbol{i}}$ \\
\hline 33 - Aydınlatma & 0,846 & 0,249 \\
\hline 32 - İniş Takımları & 0,688 & 0,204 \\
\hline 70 - Motor & 0,426 & 0,186 \\
\hline 35 - Oksijen & 0,911 & 0,289 \\
\hline 34 - Seyrüsefer & 0,575 & 0,230 \\
\hline
\end{tabular}




\begin{tabular}{|l|c|c|}
\hline 21 - İklimlendirme & 0,566 & 0,194 \\
\hline 23 - Illetişim & 0,847 & 0,255 \\
\hline 31 - Göstergeler ve Kayıt & 0,677 & 0,230 \\
\hline 27 - Uçuş Kumandaları & 0,551 & 0,213 \\
\hline 38 - Su ve Atık Su & 0,930 & 0,261 \\
\hline 30 - Buz ve Yağmur Önleme & 0,725 & 0,230 \\
\hline 28 - Yakıt & 0,900 & 0,291 \\
\hline 36 - Pnömatik & 0,574 & 0,244 \\
\hline 22 - Otomatik Uçuş & 0,696 & 0,274 \\
\hline 29 - Hidrolik Gücü & 0,769 & 0,270 \\
\hline
\end{tabular}

Adım 4: $Q_{j}$ değerlerinin hesaplanmasında 27 numaralı denklem kullanılmıştır. Maksimum grup faydasına ulaşmak için katsayı 0,5 alınmıştır. Hesaplama sonucu elde edilen değerler Tablo $16^{\prime}$ da gösterilmiştir.

Tablo 16: VIKOR İçin Hesaplanmış $\boldsymbol{Q}_{j}$ Değerleri

\begin{tabular}{|l|c|}
\hline Alternatif Uçak Sistemi & $\boldsymbol{Q}_{\boldsymbol{j}}$ \\
\hline 33 - Aydınlatma & 0,7170 \\
\hline 32 - Iniş Takımları & 0,3492 \\
\hline 70 - Motor & 0,0000 \\
\hline 35 - Oksijen & 0,9706 \\
\hline 34 - Seyrüsefer & 0,3599 \\
\hline 21 - Iklimlendirme & 0,1782 \\
\hline 23 - Iletişim & 0,7446 \\
\hline 31 - Göstergeler ve Kayıt & 0,4607 \\
\hline 27 - Uçuş Kumandaları & 0,2529 \\
\hline 38 - Su ve Atık Su & 0,8579 \\
\hline 30 - Buz ve Yağmur Önleme & 0,5090 \\
\hline 28 - Yakıt & 0,9703 \\
\hline 36 - Pnömatik & 0,4227 \\
\hline 22 - Otomatik Uçuş & 0,6888 \\
\hline 29 - Hidrolik Gücü & 0,7416 \\
\hline
\end{tabular}

Adım 5: Tablo 15 ve 16 'daki değerlerden faydalanarak $S_{j}, R_{j}$ ve $Q_{j}$ değerlerine göre alternatifler sıralanmıştır. Elde edilen sonuç Tablo 17'de görülmektedir.

Tablo 17: VIKOR için alternatiflerin üçlü sıralaması

\begin{tabular}{|l|c|c|c|c|c|c|}
\hline Alternatif Uçak Sistemi & $\boldsymbol{S}_{\boldsymbol{j}}$ & $\begin{array}{c}\boldsymbol{S}_{\boldsymbol{j}} \\
\text { Sıralaması }\end{array}$ & $\boldsymbol{R}_{\boldsymbol{j}}$ & $\begin{array}{c}\boldsymbol{R}_{\boldsymbol{j}} \\
\text { Sıralaması }\end{array}$ & $\boldsymbol{Q}_{\boldsymbol{j}}$ & $\begin{array}{c}\boldsymbol{Q}_{\boldsymbol{j}} \\
\text { Sıralaması }\end{array}$ \\
\hline 33 - Aydınlatma & 0,8461 & 11 & 0,2489 & 9 & 0,717 & 10 \\
\hline 32 - İniş Takımları & 0,6881 & 7 & 0,2045 & 3 & 0,3492 & 4 \\
\hline 70 - Motor & 0,4255 & 1 & 0,1858 & 1 & 0 & 1 \\
\hline 35 - Oksijen & 0,9109 & 14 & 0,2887 & 14 & 0,9706 & 15 \\
\hline 34 - Seyrüsefer & 0,5749 & 5 & 0,2303 & 5 & 0,3599 & 5 \\
\hline 21 - İlimlendirme & 0,5662 & 3 & 0,194 & 2 & 0,1782 & 2 \\
\hline 23 - Illetişim & 0,8465 & 12 & 0,2546 & 10 & 0,7446 & 12 \\
\hline 31 - Göstergeler ve Kayıt & 0,6766 & 6 & 0,2303 & 5 & 0,4607 & 7 \\
\hline 27 - Uçuş Kumandaları & 0,551 & 2 & 0,2128 & 4 & 0,2529 & \\
\hline 38 - Su ve Atık Su & 0,9296 & 15 & 0,2611 & 11 & 0,8579 & 13 \\
\hline 30 - Buz ve Yağmur Önleme & 0,7252 & 9 & 0,2303 & 5 & 0,509 & 8 \\
\hline 28 - Yakıt & 0,8997 & 13 & 0,291 & 15 & 0,9703 & 14 \\
\hline 36 - Pnömatik & 0,5743 & 4 & 0,2437 & 8 & 0,4227 & 6 \\
\hline 22 - Otomatik Uçuş & 0,696 & 8 & 0,2742 & 13 & 0,6888 & \\
\hline 29 - Hidrolik Gücü & 0,7686 & 10 & 0,2702 & 12 & 0,7416 & 9 \\
\hline
\end{tabular}


Adım 6: Tablo 17'deki veriler kullanılarak, 29 numaralı denkleme göre yapılan hesaplamalar sonucu, her iki koşulun sağlandığı görülmüştür. Sonuç olarak elde edilmiş nihai liste Tablo 18'de verilmiştir.

Tablo 18: VIKOR için nihai sıralama

\begin{tabular}{|l|c|}
\hline Alternatif Uçak Sistemi & Nihai Sıralama \\
\hline 33 - Aydınlatma & 10 \\
\hline 32 - İiş Takımları & 4 \\
\hline 70 - Motor & 1 \\
\hline 35 - Oksijen & 15 \\
\hline 34 - Seyrüsefer & 5 \\
\hline 21 - İlimlendirme & 2 \\
\hline 23 - Illetişim & 12 \\
\hline 31 - Göstergeler ve Kayıt & 7 \\
\hline 27 - Uçuş Kumandaları & 3 \\
\hline 38 - Su ve Atık Su & 13 \\
\hline 30 - Buz ve Yağmur Önleme & 8 \\
\hline 28 - Yakıt & 14 \\
\hline 36 - Pnömatik & 6 \\
\hline 22 - Otomatik Uçuş & 9 \\
\hline 29 - Hidrolik Gücü & 11 \\
\hline
\end{tabular}

TOPSIS ve VIKOR olmak üzere, iki farklı ÇKKV yöntemiyle yapılan nihai sıralama sonuçları Tablo 19'da görülmektedir. Her iki sıralama incelendiğinde sıralamaların birbiriyle neredeyse aynı olduğu görülmektedir. Sadece dokuzuncu sıra ile onuncu sıra ve on dördüncü sıra ile on beşinci sıra her iki modelde kendi aralarında yer değiştirmiştir. Bu tabloda görülen nihai durum, seçilen ÇKKV yöntemlerinin bu araştırma modelinde kullanılabileceğini ortaya koymuştur.

Tablo 19: Nihai sıralamaların karşılaştırılması

\begin{tabular}{|l|c|c|}
\hline Alternatif Uçak Sistemi & TOPSIS Sıralaması & VIKOR Sıralaması \\
\hline 70 - Motor & 1 & 1 \\
\hline 21 - İklimlendirme & 2 & 2 \\
\hline 27 - Uçuş Kumandaları & 3 & 3 \\
\hline 32 - İniş Takımları & 4 & 4 \\
\hline 34 - Seyrüsefer & 5 & 5 \\
\hline 36 - Pnömatik & 6 & 6 \\
\hline 31 - Göstergeler ve Kayıt & 7 & 7 \\
\hline 30 - Buz ve Yağmur Önleme & 8 & 8 \\
\hline 33 - Aydınlatma & 9 & 10 \\
\hline 22 - Otomatik Uçuş & 10 & 9 \\
\hline 29 - Hidrolik Gücü & 11 & 11 \\
\hline 23 - İletişim & 12 & 12 \\
\hline 38 - Su ve Atık Su & 13 & 13 \\
\hline 35 - Oksijen & 14 & 15 \\
\hline 28 - Yakıt & 15 & 14 \\
\hline
\end{tabular}

\section{TARTIŞMA VE SONUÇ}

Ticari hava taşımacılığındaki uçak üreticilerinin rekabette öne çıkabilmek amacıyla ürettiği her yeni modelde kullanılan yeni teknolojiler uçak sistemlerini giderek daha karmaşık hale getirmektedir. Günden güne değişen ve gelişen karmaşık uçak sistemlerine bakım yapmak sürekli olarak değişen yetkinlik ihtiyaçlarını da beraberinde getirmektedir. Bu sebeple uçak sistemlerindeki karmaşıklığı da dikkate alan yetkinlik ölçümü ve gelişimi sağlanmalıdır.

Ticari hava taşımacılığında faaliyet gösteren havayolu firmaları emniyetli bir şekilde uçuşlarını gerçekleştirmek zorundadır. Uçuş emniyetinin sağlanması için uçak sistemlerinin sorunsuz bir şekilde çalışması gereklidir. Sistemlerin sorunsuz çalışması için yapılması gereken birçok bakım işlemi vardır. Bakım işlemleri uçak bakım organizasyonları tarafından gerçekleştirilir. Çoğu 
havayolu firması kendi bakım organizasyonuna sahipken, bazı havayolu firmaları harici uçak bakım organizasyonlarıyla imzaladıkları anlaşmalarla süreci yönetmektedirler. Bakım organizasyonlarında çalışan yetkin olmayan personel bakım hatalarına, gereksiz söküm takım işlemlerine, çözülemeyen arızalara sebep olabilir. Bu sebeple, sistemlerde karşılaşılan arızalardan ne kadarının zamanında çözülemediği bakım personelinin yetkinliği açısından takip edilmesi gereken parametrelerden birisidir.

Uçaklarda karşılaşılan arızalar çalışmasını etkilediği uçak sistemine bağı olarak farklı türde operasyonel etki veya risk ortaya çıkarır. Kimi zaman uçuşun gecikmesine veya ekstra yakıt yakılmasına sebep olabilirken, kimi zaman acil iniş gerektiren riskli durumları ortaya çıkarabilir. Bu sebeple plansız arızaların sayısı ve bu arızaların hangi sistemlerde ortaya çıktığı operasyonel etkileriyle ve riskleriyle birlikte değerlendirilmelidir.

Bakım organizasyonlarında bakımı gerçekleştirmekten sorumlu olan bakım personeli çeşitli sebeplerle yetkinliğini en etkin düzeyde kullanamayabilir. Bu sebepler çevresel kaynaklı, işletme kaynaklı veya uçak sistemi kaynaklı olabilir. Sebepler işletme tarafından saptanabilirse ortadan kaldırmak ve personel yetkinliğinden en iyi düzeyde faydalanmak mümkün olacaktır. Bu sebeple personele uygulanmış anket, işletme yönetimi tarafından görülemeyen bazı gizli sorunların ortaya çıkarılması açısından faydalı olacaktır. Bu nedenle anket sonuçları değerlendirilmesi gereken bir diğer parametredir.

Ticari hava taşımacılığı ulusal ve uluslararası talimatlarla yönetilen bir sektördür. Her ülkenin sorumlu otoritesi kendi sınırları içerisinde uyulması gereken kuralları belirler. Bu otoriteler tarafından yayınlanan talimatlarda hava aracı bakım personelinde olması gereken minimum yetkinlikler tanımlanmıştır. Bu yetkinlikler uçak bakım işletmeleri tarafından yetkileri kapsamındaki uçak tiplerine ve bakım türlerine bağı olarak azaltılmamak kaydıyla artırılabilir. İşletmenin ihtiyaç duyduğu yetkinliklere göre oluşturulacak anket soruları değerlendirilmesi gereken bir diğer parametredir.

Uçaklara uygulanan büyük bakım işlerini gerçekleştiren bakım organizasyonları çoğunlukla bir havayolu firmasına bağı ı değildirler. Bu tür organizasyonlarda oluşan bakım hataları bakım çıkışında karşılaşılan plansız arızalara sebep olur. Bu durumda arızaların çoğunlukla uçuşla ilgili operasyonel etkileri veya riskleri olmaz. Ancak, bir havayolu firmasına bağlı olarak faaliyet gösteren ve küçük bakım işlerini gerçekleştiren uçak bakım organizasyonlarında karşılaşılan arızalar çoğunlukla uçuş gecikmelerine sebep olur. İşletmelerin faaliyetlerindeki bu tür değişiklikler bakımın etkinliğini veya bakım hatalarını takip edebilmek için farklı türde operasyonel kriterlerin belirlenmesini gerektirir.

Sonuç olarak, uçak bakım personelinin doğrudan işi ile ilgili parametrelerin hepsi yetkinlik değerlendirilmesinde dikkate alınması gereken ayrı bir boyuttur. Bu parametrelerin sayısı ve ağırlığı her işletme için farklılık gösterecektir. Bu sebeple personelin yetkinliğini geliştirmek için sahip olunan sınırlı kaynakların hangi yönde kullanılmaya başlanacağını belirlemek karmaşık bir karar verme problemini ortaya çıkarır. Bu problemi çözmek için literatürde var olan ÇKKV yöntemlerinden AHP, TOPSIS ve VIKOR kullanılmıştır. Hesaplamalar sonucunda elde edilen sıralamaların birbiri ile benzerlik göstermesi oluşturulan modelin seçilen ÇKKV yöntemleriyle kullanılabileceğini göstermiştir.

Çalışma neticesinde elde edilen nihai sıralamalar incelendiğinde, nihai sıralamada TOPSIS'e göre dokuzuncu ve VIKOR'a göre onuncu sırada olan 33 - Aydınlatma Sistemi diğer sistemler arasında en yüksek plansız bakım sayısına sahiptir. Nihai sıralamada TOPSIS'e göre onuncu ve VIKOR'a göre dokuzuncu sırada olan 22 - Otomatik Uçuş sistemi diğer sistemler arasında en düşük anket skoruna sahiptir. Nihai sıralamada TOPSIS ve VIKOR'a göre altıncı sırada olan 36 - Pnömatik sistemi diğer sistemler arasında operasyonel etki açısından en yüksek ağırlığa sahiptir. Sonuç olarak önemli olan uçak sistemlerinin belirlenmesinde tek bir parametreye bakılamayacağı görülmüştür. Doğru uçak sistemini seçmek için bakımın etkinliğini gösteren ve bakım personelinin yetkinliğiyle ilişkili tüm boyutların sürece dahil edilmesi gerekmektedir. Bu araştırma modeliyle ortaya konulmuş olan "Çok Boyutlu Yetkinlik Değerlendirmesi" uçak bakım işletmeleri tarafından belirli aralıklarla veya dinamik olarak yapılmalıdır. Çünkü veriler işletmenin faaliyetlerine veya uçak sistemlerindeki teknolojik değişikliklere göre sürekli bir değişkenlik içerisindedir. Dinamik olarak yapılan bu değerlendirme modeli aracılığıyla saptanan noktalar değişen şartlar içerisinde odaklanılması gereken konuları sürekli olarak ön planda tutacaktır.

Araştırma sonucunda elde edilen sıralamada ilk beş sistem için ankete verilen cevaplar incelenmiş ve geliştirilmesi gereken yetkinlik konuları saptanmıştır. Anket sonuçlarına göre beşinci ve altıncı sorulara katılımcıların büyük bir çoğunluğunun tam puan verdiği görülmektedir. Bu durum, katılımcıların bakım uygulamaları esnasında emniyetten taviz vermediklerini, emniyeti önleme ve güncel bakım el kitaplarına göre çalışma konularında kendilerini son derece yeterli gördüklerini göstermektedir. Verileri daha iyi yorumlayabilmek amacıyla, anketten elde edilen skorlar üç farklı kategoriye ayrılmış ve bu kategoriler renklerle ifade edilmiştir. Kırmızı ile ifade edilen alanlar (anket skoru $<4,50$ ) geliştirilmesi öncelikli olarak önemli olan alanları göstermektedir. Turuncu ile gösterilen alanlar $(4,50<$ anket skoru < 4,75) kırmızıların geliştirilmesi sırasında dikkate alınması gereken diğer alanları göstermektedir. Yeşil ile gösterilen alanlar (anket skoru > 4,75) ilk aşamada geliştirilmesine gerek duyulmayan alanları göstermektedir. 
Tablo 20: Nihai sıralamalara göre ilk beş sistemin anket skorları

\begin{tabular}{|c|c|c|c|c|c|}
\hline $\begin{array}{c}\text { Anket Soru } \\
\text { Numarası }\end{array}$ & Motor & iklimlendirme & Uçuş Kumandaları & iniş Takımları & Seyrüsefer \\
\hline 2. soru & 4,62 & 4,64 & 4,23 & 4,51 & 4,42 \\
\hline 3. soru & 4,48 & 4,71 & 4,52 & 4,53 & 4,38 \\
\hline 4. soru & 4,32 & 4,64 & 4,32 & 4,54 & 4,42 \\
\hline 5. soru & 5,00 & 5,00 & 5,00 & 5,00 & 5,00 \\
\hline 6. soru & 4,98 & 4,98 & 4,97 & 4,98 & 4,97 \\
\hline
\end{tabular}

Sıralamada birinci olan uçak motor sistemi için anket sonuçları incelendiğinde, üçüncü ve dördüncü sorunun kırmızı kategoride, ikinci sorunun ise turuncu kategoride olduğu görülmektedir. Dördüncü sorunun skoru sistemin detaylı bilgisi hakkında katılımcıların kendilerini yeterli görmediklerini göstermektedir. Bir sonraki düşük skor üçüncü soruda elde edilmiştir. Üçüncü sorunun skoru sistem arıza raporları/göstergeleri hakkında katılımcıların kendilerini yeterli görmediklerini göstermektedir. Kırmızı kategorideki bu iki alana isabet eden uçak motor sisteminin detayları ve sistemin arıza raporları/göstergeleri konusunda uçak bakım personelinin geliştirilmesi için iyileştirme çalışması yapılması gerekmektedir. Bu sistemde yapılacak bir sonraki iyileştirme çalışması ikinci soruya isabet eden sistemin diğer sistemlerle etkileşimini anlama, bakımı planlama ve uygulama hakkında olmalıdır.

Sıralamada ikinci olan iklimlendirme sistemi için anket sonuçları incelendiğinde, ikinci, üçüncü ve dördüncü sorunun turuncu kategoride olduğu görülmektedir. Bu sistemde kırmızı kategoride alan bulunmamaktadır. Bu sebeple, bu sistem hakkındaki iyileştirme çalışması diğer kırmızı kategori alana sahip sistemlerin iyileştirme çalışmalarının tamamlanmasından sonraya bırakılabilir. İkinci sorunun skoru sistemin diğer sistemlerle etkileşimini anlama, bakımı planlama ve uygulama hakkında katılımcıların kendilerini istenen düzeyde görmediklerini göstermektedir. Üçüncü sorunun skoru sistem arıza raporları/göstergeleri hakkında katılımcıların kendilerini istenen düzeyde görmediklerini göstermektedir. Dördüncü sorunun skoru sistemin detaylı bilgisi hakkında katılımcıların kendilerini istenen düzeyde görmediklerini göstermektedir. Turuncu kategorideki bu üç alana isabet eden iklimlendirme sisteminin detayları, sistemin arıza raporları/göstergeleri ve sistemin diğer sistemlerle etkileşimini anlama, bakımı planlama ve uygulama konusunda uçak bakım personelinin geliştirilmesi için iyileştirme çalışması yapılması gerekmektedir.

Sıralamada üçüncü olan uçuş kumandaları sistemi için anket sonuçları incelendiğinde, ikinci ve dördüncü sorunun kırmızı kategoride, üçüncü sorunun ise turuncu kategoride olduğu görülmektedir. İkinci sorunun skoru sistemin diğer sistemlerle etkileşimini anlama, bakımı planlama ve uygulama hakkında katılımcıların kendilerini yeterli görmediklerini göstermektedir. Bir sonraki düşük skor dördüncü soruda elde edilmiştir. Dördüncü sorunun skoru sistemin detaylı bilgisi hakkında katılımcıların kendilerini yeterli görmediklerini göstermektedir. Kırmızı kategorideki bu iki alana isabet eden uçuş kumandaları sisteminin detayları ve sistemin diğer sistemlerle etkileşimini anlama, bakımı planlama ve uygulama konusunda uçak bakım personelinin geliştirilmesi için iyileştirme çalışması yapılması gerekmektedir. Bu sistemde yapılacak bir sonraki iyileştirme çalışması üçüncü soruya isabet eden sistem arıza raporları/göstergeleri hakkında olmalıdır.

Sıralamada dördüncü olan iniş takımları sistemi için anket sonuçları incelendiğinde, ikinci, üçüncü ve dördüncü sorunun turuncu kategoride olduğu görülmektedir. Bu sistemde kırmızı kategoride alan bulunmamaktadır. Bu sebeple, bu sistem hakkındaki iyileştirme çalışması diğer kırmızı kategori alana sahip sistemlerin iyileştirme çalışmalarının tamamlanmasından sonraya bırakılabilir. İkinci sorunun skoru sistemin diğer sistemlerle etkileşimini anlama, bakımı planlama ve uygulama hakkında katılımcıların kendilerini istenen düzeyde görmediklerini göstermektedir. Üçüncü sorunun skoru sistem arıza raporları/göstergeleri hakkında katılımcıların kendilerini istenen düzeyde görmediklerini göstermektedir. Dördüncü sorunun skoru sistemin detaylı bilgisi hakkında katılımcıların kendilerini istenen düzeyde görmediklerini göstermektedir. Turuncu kategorideki bu üç alana isabet eden iniş takımları sisteminin detayları, sistemin arıza raporları/göstergeleri ve sistemin diğer sistemlerle etkileşimini anlama, bakımı planlama ve uygulama konusunda uçak bakım personelinin geliştirilmesi için iyileştirme çalışması yapılması gerekmektedir.

Sıralamada beşinci olan seyrüsefer sistemi için anket sonuçları incelendiğinde, ikinci, üçüncü ve dördüncü sorunun kırmızı kategoride olduğu görülmektedir. İkinci sorunun skoru sistemin diğer sistemlerle etkileşimini anlama, bakımı planlama ve uygulama hakkında katılımcıların kendilerini yeterli görmediklerini göstermektedir. Üçüncü sorunun skoru sistem arıza raporları/göstergeleri hakkında katılımcıların kendilerini yeterli görmediklerini göstermektedir. Dördüncü sorunun skoru sistemin detaylı bilgisi hakkında katılımcıların kendilerini yeterli görmediklerini göstermektedir. Kırmızı kategorideki bu üç alana isabet eden seyrüsefer sisteminin detayları, sistemin arıza raporları/göstergeleri ve sistemin diğer sistemlerle etkileşimini anlama, bakımı planlama ve uygulama konusunda uçak bakım personelinin geliştirilmesi için iyileştirme çalışması yapılması gerekmektedir. 
Tüm bu sonuçların anlaşılmasını ve yorumlanmasını kolaylaştırmak açısından sonuçların özetlenmiş hali Tablo 21'de görülmektedir. Personel yetkinliğinin geliştirilmesi açısından teorik eğitim, pratik eğitim veya iş başı eğitimi gibi yöntemler eldeki kaynaklara göre kullanılabilir. Kaynakların miktarına bağı olarak bu çalışma ilk beş sistem yerine sıralamaya dahil edilmiş tüm sistemler için yapılabilir. Ankette sorulacak soruların çeşitliliği elde edilecek sonuçları daha da detaylandıracaktır.

Tablo 21: Uçak sistemleri bazında geliştirilmesi gereken alanlar

\begin{tabular}{|l|l|l|}
\hline Uçak sistemi & Birinci öncelik & ikinci öncelik \\
\hline Motor & $\begin{array}{l}\text { Sistemin detayları ve sistemin arıza } \\
\text { raporları/göstergeleri }\end{array}$ & $\begin{array}{l}\text { Sistemin diğer sistemlerle etkileşimini anlama, bakımı } \\
\text { planlama ve uygulama }\end{array}$ \\
\hline İlimlendirme & $\begin{array}{l}\text { Sisteminin detayları, sistemin arıza } \\
\text { raporları/göstergeleri ve sistemin diğer sistemlerle } \\
\text { etkileşimini anlama, bakımı planlama ve uygulama }\end{array}$ \\
\hline $\begin{array}{l}\text { Uçuş } \\
\text { Kumandaları }\end{array}$ & $\begin{array}{l}\text { Sistemin detayları ve sistemin diğer sistemlerle } \\
\text { etkileşimini anlama, bakımı planlama ve uygulama }\end{array}$ & Sistem arıza raporları/göstergeleri \\
\hline Iniş Takımları & $\begin{array}{l}\text { Sistemin detayları, sistemin arıza } \\
\text { raporları/göstergeleri ve sistemin diğer sistemlerle } \\
\text { etkileşimini anlama, bakımı planlama ve uygulama }\end{array}$ \\
\hline Seyrüsefer & $\begin{array}{l}\text { Sistemin detayları, sistemin arıza } \\
\text { raporları/göstergeleri ve sistemin diğer } \\
\text { sistemlerle etkileşimini anlama, bakımı planlama } \\
\text { ve uygulama }\end{array}$ & \\
\hline
\end{tabular}

Emniyetin çok önemli olduğu ticari hava taşımacılığında uçak bakım personelinin yetkinliğini geliştirmek asla unutulmamalıdır. Küresel boyutta çetin rekabetlerin yaşandığı havacılık sektöründe emniyeti artırırken maliyetleri de aşağı çekecek dinamik bir değerlendirme sisteminin varlığı son derece büyük önem taşımaktadır. Bu çalışma ile ortaya konulmuş olan "Çok Boyutlu Yetkinlik Değerlendirmesi" modeli günümüzde faaliyet gösteren tüm uçak bakım ve havayolu organizasyonları tarafından uygulanabilir. Model temel alındıktan sonra, uygulamayı yapacak işletme tarafından belirlenecek operasyonel kriterler, kriterlere verilen ağırlık değerleri, toplanan bakım verileri, oluşturulacak anket soruları ve personelin ankete vereceği cevaplar çalışmayı ilgili işletme için özelleştirilmiş hale getirecektir. Elde edilecek sonuçlar uçak bakım personelinin yetkinlik gelişimi için önemli olan Tablo 21 'dekine benzer şekilde konu başlıklarını verecektir. Hatta yapılacak uygulamada kullanılan bakım verileri kişi bazlı toplanabilirse, bakım organizasyonunda çalışan her bir uçak bakım personelinin geliştirilmesi gereken yetkinlik alanlarına ulaşmak mümkün olacaktır. Bu sayede kişiler için eğitim gerekliliği olan konular saptanabileceği gibi, havayolu firmalarında kalite departmanları tarafından yetkilendirme amacıyla belirli aralıklarla yapılan değerlendirmelerde sorgulanması gereken konular listesi oluşturmak da mümkün olacaktır. Nihai olarak bu model, uçak bakım organizasyonundaki uçak bakım personelinin tamamı için özelleştirilmiş sonuçlar verirken, kişi bazlı veriler kullanılarak yapıldığında kişi için özelleştirilmiş sonuçlar da verecektir.

$\mathrm{Bu}$ modelin geliştirilmesi için farklı yetki ve uçak tiplerine sahip uçak bakım organizasyonlarında, farklı ÇKKV yöntemleri kullanılarak, daha detaylı sorulara sahip anketler aracılığıyla yeni çalışmalar yapılabilir. Kişi bazlı geliştirilmesi gereken alanların saptanması için veriler kişi bazlı toplanabilir ve bu toplanan verilerle kalite departmanları tarafından yapılan yetkinlik değerlendirmesinde sorgulanması gereken konuların oluşturulması sağlanabilir.

\section{KAYNAKÇA}

Behzadian, M., Otaghsara, S. K., Yazdani, M., Ignatius, J. (2012). A state-of the-art survey of TOPSIS applications. Expert Systems with Applications. 39, 13051-13069.

Benmoussa, N., Elyamami, A., Mansouri, K., Qbadou, M., Illoussamen, E. (2019). A multi-criteria decision making approach for enhancing university accreditation process. Engineering, Technology \& Applied Science Research. 9 (1), 3726-3733.

Bongo, M. F., Alimpangog, K. M. S., Loar, J. F., Montefalcon, J. A., Ocampo, L. A. (2018). An application of DEMATEL-ANP and PROMETHEE II approach for air traffic controllers' workload stress problem: A case of Mactan Civil Aviation Authority of the Philippines. Journal of Air Transport Management. 68, 198-213.

Büyüktürk, M. A., (2019). Avrupa birliği ülkeleri ve Türkiye'nin inovasyon performansının çok kriterli karar verme yöntemleriyle kıyaslanması. Yüksek Lisans Tezi. Kayseri: Nuh Naci Yazgan Üniversitesi SBE.

CAA, CAP 1367, Aircraft maintenance incident analysis, 2016, https://publicapps.caa.co.uk/docs/33/CAP 1367 template w charts.pdf [erişim tarihi 30.10.2019]. 
Chen, L., \& Ren, J. (2018). Multi-attribute sustainability evaluation of alternative aviation fuels based on fuzzy ANP and fuzzy grey relational analysis. Journal of Air Transport Management. 68, 176-186.

Chiu, M. C., \& Hsieh, M. C. (2016). Latent human error analysis and efficient improvement strategies by fuzzy TOPSIS in aviation maintenance tasks. Applied Ergonomics. 54, 136-147.

Cakırkaya, M. ve Acar, O. E. (2016). Bir üretim hattında meydana gelen hataların önem derecelerinin istatistiksel proses kontrol tekniklerinden pareto analizi ile belirlenmesi. Mustafa Kemal Üniversitesi Sosyal Bilimler Enstitüsü Dergisi. 13 (26), 272-288.

Celik, D. S., (2017). Uluslararası havayolu yolcu taşımacılığı: Çok kriterli karar verme teknikleri ile gelir yönetimi uygulaması. Doktora Tezi. İstanbul: İstanbul Üniversitesi SBE.

Cetinkaya, S., (2019). Performance evaluation of airline companies from consumers' perspective based on TOPSIS and VIKOR methods. Yüksek Lisans Tezi. İstanbul: Marmara Üniversitesi SBE.

Citli, M. N., (2006). Bulanık çok kriterli karar verme. Yüksek Lisans Tezi. İstanbul: Yıldız Teknik Üniversitesi FBE.

Dalkılıç, S. (2017). Improving aircraft safety and reliability by aircraft maintenance technician training. Engineering Failure Analysis. (82), 687-694.

Dinçer, H. ve Görener, A. (2011). Performans değerlendirmesinde AHP - VIKOR ve AHP - TOPSIS yaklaşımları: hizmet sektöründe bir uygulama. Sigma Dergisi. (29), 244-260.

Dolan, J. G. (2008). Shared decision-making - transferring research into practice: The Analytic Hierarchy Process (AHP). Patient Education and Counseling. 73, 418-425.

Dozic, S. (2019). Multi-criteria decision making methods: Application in the aviation industry. Journal of Air Transport Management. $79,101683$.

Dozic, S., Lutovac, T., Kalic, M. (2018). Fuzzy AHP approach to passenger aircraft type selection. Journal of Air Transport Management. 68, 165175.

EASA, Easy Access Rules for Continuing Airworthiness, 2019, https://www.easa.europa.eu/newsroom-and-events/news/easy-access-rulescontinuing-airworthiness-updated [erişim tarihi 17.12.2019], s.34.

EASA, MMEL Manual, (2008), https://www.easa.europa.eu/system/files/dfu/certification-flight-standards-doc-oeb-supporting-documents-tglTGL26-section-2-REV10.doc [erişim tarihi 17.12.2019].

Erçetin, F. B., (2019). Özel okullarda stratejik yönetim sürecinde swot analizinin çok kriterli karar verme yöntemi ile entegrasyonu ve bir uygulama. Yüksek Lisans Tezi. İstanbul: Marmara Üniversitesi SBE.

Ertugrul, i. ve Ozcil, A. (2014). Çok kriterli karar vermede TOPSIS ve VIKOR yöntemleriyle klima seçimi. Çankırı Karatekin Üniversitesi iktisadi ve Idari Bilimler Fakültesi Dergisi. 4 (1), 267-282.

Gerede, E., (1998). Bakım maliyetlerinin incelenmesi ve direkt bakım maliyetlerinin azaltılması için öneriler geliştirilmesi Türkiye uygulaması. Yüksek Lisans Tezi. Eskişehir: Anadolu Üniversitesi SBE.

Gokalp, B. ve Soylu, B. (2010). Tedarikçinin süreçlerini iyileştirme amaçlı tedarikçi seçim problemi. Endüstri Mühendisliği Dergisi. 23 (1), 4-15.

Gupta, H. (2018). Evaluating service quality of airline industry using hybrid best worst method and VIKOR. Journal of Air Transport Management. 68, 35-47.

Gunes, H., (2019). Ankara ilinde bitümlü sıcak karışım kaplamalı yollarda kullanılan agregaların uygunluklarının belirlenmesi ve çok kriterli karar verme yöntemleri ile sınıflandırılması. Yüksek Lisans Tezi. Konya: Konya Teknik Üniversitesi FBE.

Guntut, C., (2019). Bulanık TOPSis yöntemiyle düşük maliyetli bir havayolu için filo planlama optimizasyonu. Yüksek Lisans Tezi. Ankara: Türk Hava Kurumu Üniversitesi SBE.

Hsia, T. C., Chen, H. T., Chen, W. H. (2008). Measuring the readability performance (RP) of aircraft maintenance technical orders by fuzzy MCDM method and RP index. Qual Quant. 42, 795-807.

ICAO, Doc 9859 Safety Management Manual, (2018), http://web.shgm.gov.tr/tr/kurumsal-yayinlar/6083-icao-doc-9859-emniyet-yonetimi-elkitabi-dorduncu-baski [erişim tarihi 03.03.2020].

Incel, E., (2019). Bir işletmede bulanık çok kriterli karar verme yöntemleriyle iş sağlığı ve güvenliği açısından riskli alanların belirlenmesi. Yüksek Lisans Tezi. Kocaeli: Kocaeli Üniversitesi FBE.

ibicioglu, H. ve Unal, O. F. (2014). Analitik hiyerarşi prosesi ile yetkinlik bazlı insan kaynakları yöneticisi seçimi. Atatürk Üniversitesi iktisadi ve Idari Bilimler Dergisi. 28 (4), 55-78.

Jamali, N., \& Khameneh, M. M. (2016). Using a fuzzy AHP-VIKOR and BSC approach for evaluating aircraft maintenance unit performance. International Journal of Management, Accounting and Economics. 3 (10), 141-149.

Karim, R., Karmaker, C. L. (2016). Machine selection by AHP and TOPSIS methods. American Journal of Industrial Engineering. 4 (1), 7-13. 
Kecek, G. ve Yüksel, R. (2016). Analitik hiyerarşi süreci (AHP) ve PROMETHEE teknikleriyle akıllı telefon seçimi. Sosyal Bilimler Dergisi. (49), 46-62.

Liang, G. F., Lin, J. T., Hwang, S. L., Wang, E. M., Patterson, P. (2010). Preventing human errors in aviation maintenance using an on-line maintenance assistance platform. International Journal of Industrial Ergonomics. 40, 356-367.

Marais, K. B., \& Robichaud, M. R. (2012). Analysis of trends in aviation maintenance risk: An empirical approach. Reliability Engineering and System Safety. (106), 104-118.

Mercan, E., (1999). Havayolu ve havacılık işletmelerinde uçak bakım organizasyonu. Yüksek Lisans Tezi. Eskişehir: Anadolu Üniversitesi SBE.

Onen, V. (2018). Uçak bakım kuruluşlarında tedarikçi değerlendirmeleri: Analitik hiyerarşi prosesiyle tedarikçi seçimine yönelik bir bakım kuruluşu uygulaması. Uluslararası Sosyal Bilimler Dergisi. 2 (13), 84-109.

Ozdemir, F., (2019). Multi criteria decision making approaches in a new destination selection for airlines. Yüksek Lisans Tezi. İstanbul: Galatasaray Üniversitesi FBE.

Percin, S. (2018). Evaluating airline service quality using a combined fuzzy decision-making approach. Journal of Air Transport Management. 68, 48-60.

Sadatrasool, M., Amiri, A. B., \& Babadi, A. Y., (2017). Project manager selection based on project manager competency model: PCA-MCDM approach. International Journal of Project Management, [online] 20 January 2017, 1 (1), 7-20.

SHGM, SHT-66 Hava aracı bakım personeli lisansı talimatı, (2018), http://mevzuat.shgm.gov.tr/index.php/talimat/ [erişim tarihi17.12.2019].

SHGM, SHT-SMS Ticari hava taşıma işletmeleri, uçuş eğitim ve bakım, tasarım ve üretim kuruluşlarında emniyet yönetim sisteminin uygulanmasına ilişkin talimat, 2015, http://mevzuat.shgm.gov.tr/index.php/talimat/ [erişim tarihi 17.12.2019].

Sıktaslı, G., (2019). Sivil havacılık sektöründe uçak bakım maliyetlerinin yıllara göre incelenmesi: İstanbul'da kurulu bir uçak bakım firması üzerine bir uygulama. Yüksek Lisans Tezi. İzmir: Dokuz Eylül Üniversitesi SBE.

Stoner, J. A. ve Freeman, R. E. (1989). Management. 4.Baskı. New Delhi: Pentice Hall.

Sofu, F., (2018). Bulanık ortamda çok kriterli karar verme yöntemi ile personel seçimi: havacılık sektöründe bir uygulama. Yüksek Lisans Tezi. İstanbul: İstanbul Ticaret Üniversitesi FBE.

Tummala, V. M. R., \& Ling, H. (1998). A note on the computation of the mean random consistency index of the AHP. Theory and Decision. 44, 221230.

Wu, H., Chen, Jui., \& Chen, I. (2012). Performance evaluation of aircraft maintenance staff using a fuzzy MCDM approach. International Journal of Innovative Computing, Information and Control. 8 (6), 3919-3937.

Zimmermann, H. J. (2001). Fuzzy set theory and its applications. New York: Springer Science+Business Media. 